\title{
Ten new species of Telipogon (Orchidaceae, Oncidiinae) from southern Peru
}

\author{
by \\ William Nauray Huari ${ }^{1} \&$ Antonio Galán de Mera² \\ ${ }^{1}$ Programa de Doctorado en Medio Ambiente, Universidad de Gerona, 17071 Montilivi s/n, Gerona, Spain \\ wnauray@gmail.com \\ ${ }^{2}$ Departamento de Ciencias Ambientales y Recursos Naturales (Botánica), Facultad de Farmacia, Universidad San Pablo-CEU, \\ Apartado 67, 28660 Boadilla del Monte, Madrid, Spain. agalmer@ceu.es
}

\begin{abstract}
Nauray Huari, W. \& Galán de Mera, A. 2008. Ten new species of Telipogon (Orchidaceae, Oncidiinae) from southern Peru. Anales Jard. Bot. Madrid 65(1): 73-95.

Ten new species of Telipogon, T. antisuyuensis, T. austroperuvianus, T. casadevalliae, T. farfanii, T. javiercastroviejoi, T. kosnipatensis, T. marleneae, T. mesotropicalis, T. santiagocastroviejoi, and T. tupayachii are described and illustrated. These are terrestrial or epiphytes of the montane humid forests from Andean valleys of southern Peru. Diagnostic morphological characters are discussed for each species. A key is provided for the species of the genus found in southern Peru. The number of Telipogon species currently recognized for the Peruvian flora is 46 .
\end{abstract}

Keywords: Andean Mountains, Orchidaceae, Peru, Taxonomy, Telipogon.

\section{Introduction}

Telipogon Kunth is an orchid genus in subtribe Oncidiinae (Williams \& al., 2005) with flowers with four pollinia (vs. two in most other members of Oncidiinae), column normally with trichomes and bristles (rarely glabrescent) and an uncinate viscidium (Schweinfurth, 1960; Dodson, 2004) that grow as terrestrial or epiphytes in montane rain forests from Central America to Bolivia and Hispaniola in the Caribbean (Foldats, 1970; Dodson \& Escobar, 1987; Govaerts, 2008).

In Peru, 37 species of Telipogon sensu stricto have been recorded (Schweinfurth, 1960; Brako \& Zarucchi, 1993; Bennett \& Christenson, 1998, 2001; Nauray \& Christenson, 2003; Moretz \& Farfán, 2003; Galiano \& al., 2003). The genus was based on a later concept of some species, as T. benedicti Rchb. f., T.

\section{Resumen}

Nauray Huari, W. \& Galán de Mera, A. 2008. Diez especies nuevas de Telipogon (Orchidaceae, Oncidiinae) del sur del Perú. Anales Jard. Bot. Madrid 65(1): 73-95 (en inglés).

Se describen e ilustran diez especies nuevas de Telipogon -T. antisuyuensis, T. austroperuvianus, T. casadevalliae, T. farfanii, T. javiercastroviejoi, T. kosnipatensis, T. marleneae, T. mesotropicalis, $T$. santiagocastroviejoi y $T$. tupayachii. Éstas son plantas terrestres o epífitas de los bosques húmedos montanos de los valles andinos del sur de Perú. Se discuten sus caracteres morfológicos diagnósticos y se propone una clave dicotómica para diferenciar las especies que crecen en el sur del país. El número de especies de Telipogon actualmente reconocidas para la flora peruana es de 46.

Palabras clave: Cordillera Andina, Orchidaceae, Perú, Taxonomía, Telipogon.

boissierianus Rchb. f., T. papilio Rchb. f. \& Warsz., T. tessellatus Lindl., that now have updated distributions, and a high number of microspecies especially described by Braas $(1981,1982,1985)$ and Dodson \& Bennett (1989). Most of these are endemic to small areas in the country, even a single valley.

The taxonomy of the genus is complicated, especially because of the large extent of this country, the rare populations, and the few species records. For this reason, for the moment we have limited our study to the specimens collected in the Andean valleys of the Department of Cusco in southern Peru.

\section{Material and Methods}

Specimens of Telipogon species were collected from the montane rain forests of the localities Urubamba, La 
Convención, Calca, Paucartambo and Quispicanchis (Fig. 1), from 1500 to 3650 m elevation in the Amazonian slope of the Andes of the Department of Cusco in Peru. For each plant, photographs were taken and the flowers were preserved in alcohol $(70 \%)$ to be used in the preparation of illustrations. Vouchers were deposited in the herbaria CUZ, HGI, MA, and MOL.

These specimens were compared with material from Colombia, Ecuador, North and Central Peru, and Bolivia from the herbaria AMES, B, CUZ, F, G, K, MA, MO, MOL, P, SEL, TNS, USM, and W. The protologues and other published descriptions of Telipogon species from Peru and other adjacent Andean countries were reviewed (Lindley, 1847; Reichenbach, 1854, 1856, 1858, 1877a, 1877b; Kränzlin, 1919; Schlechter, 1920, 1921; Schweinfurth, 1960; Braas 1981, 1982, 1985; Dodson \& Escobar, 1987, 1993a, 1993b; Dodson \& Dodson, 1989; Dodson \& Bennett, 1989; Hashimoto, 1990; Bennett \& Christenson, 1998, 2001; Nauray \& Christenson, 2003; Moretz \& Farfán, 2003; Galiano \& al., 2003).

\section{Taxonomic treatment}

IDENTIFICATION KEY FOR THE SOUTH-PERUVIAN SPECIES OF TELIPOGON (THIS REGION INCLUDES THE DEPARTMENTS OF APURIMAC, Ayacucho, Cusco, Huancavelica, Madre de Dios and PUNO).

1. Stem $>10 \mathrm{~cm}$, leafy throughout; sheath not articulated with the leaf blade

1. Stem $<10 \mathrm{~cm}$, with few leaves at the base; sheath articulated with the leaf blade ............................................. 10

2. Flowers $>3.5 \mathrm{~cm}$ in diameter; lip different from the petals in size and coloration, without callus ..................... . vargasii

2. Flowers $<3.5 \mathrm{~cm}$ in diameter; lip similar to the petals in size and coloration, with callus .............................................. 3

3. Apex of the column trilobulate .......................................

3. Apex of the column simple ...........................................5

4. Petals obovate-rhombic; petals and lip with branched veins and transverse lines; column setose ................ T. tupayachii

4. Petals broadly elliptic; petals and lip with unbranched veins and tiny dots; column glabrescent.....

..T. phuyupatamarcensis

5. Leaves pubescent; callus a low lunate ridge

T. tayacajaensis

5. Leaves glabrescent; callus cordiform, sagittate or Y-shaped ..

Petals and lip with longitudinal veins and tiny dots; callus apex dorso-ventrally split

T. javiercastroviejoi

6. Petals and lip with longitudinal veins and sometimes transverse lines; callus apex entire

7. Petals and lip with both longitudinal veins and transverse lines; callus typically cordiform

.T. mesotropicalis

7. Petals and lip with only longitudinal veins, without transverse lines; callus Y-shaped or sagittate

8. Petals and lip golden yellow with purple veins; lip broadly ovate; callus convex, keeled in the front.....T. casadevalliae

8. Petals and lip cream yellow with purple to brown reddish veins; lip elliptic; callus flat or with a plateau in the front ....9
9. Callus Y-shaped, flat; column short pubescent

\section{T. machupicchuensis}

9. Callus sagittate, with a plateau in the front, column with bristles to $1.5 \mathrm{~mm}$ long

T. kosnipatensis

10. Lip smooth or with the base swollen, but without callus.11

10. Lip with conspicuous callus ........................................ 15

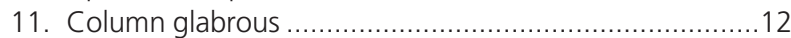

11. Column with bristles ..............................................13

12. Flowers ca. $6 \mathrm{~cm}$ in diameter, petals with ca. 13 nerves, lip with ca. 29-31 nerves ............................... peruvianus

12. Flowers ca. $4-5 \mathrm{~cm}$ in diameter, petals with ca. 9 nerves, lip with ca. 15 nerves

T. alegriae

13. Petals and lip with conspicuous purple to reddish brown spots, without longitudinal veins

T. suarezii

13. Petals and lip without spots, with longitudinal broad purplish veins

14. Lip with ca. 23 nerves, column with two lateral tufts of bristles

T. collantesii

14. Lip with ca. 13 nerves, column with three tufts of bristles...

T. austroperuvianus

15. Callus almost completely attached to the lip; petals and lip with broad longitudinal veins, transverse lines, bars, and reticulated veins

16

15. Callus attached to the lip by its base, free in the apical half; petals and lip only with reticulated veins........................18

16. Petals and lip with broad longitudinal veins and some transverse basal lines; column bristles with acuminate apex.

.T. antisuyuensis

16. Petals and lip with reticulated veins or transverse bars; column bristles capitate to subulate at apex......................17

17. Lip similar in size to petals; lip with ca. 11-13 nerves...........

T. phalaenopsis

17. Lip 1/3 smaller than petals, lip with ca. 29-31 nerves

T. salinasiae

18. Callus trilobulate, lip emarginate .................. marleneae

18. Callus sagittate or sagittate-cordiform, lip obtuse to acuminate.

19. Flowers ca. $4-5.3 \mathrm{~cm}$ in diameter, stigma trilobulate; reticulated veins thinner and colourless toward the margin

T. farfanii

19. Flowers ca. $3-3.5 \mathrm{~cm}$ in diameter, stigma round; reticulated veins thicker and coloured toward the margin .

T. santiagocastroviejoi

\section{Description of new species}

Telipogon antisuyuensis Nauray \& A. Galán, sp. nov.

Type: PERU. Cusco: Calca, Valle de Lares, Mant'o, $12^{\circ}$ 59' 4.8” S, 72 03' 45.8” W, 2564 m, 15 Feb. 2007, W. Nauray, R. Titto E T. Espinoza 3754 (holotype, CUZ; isotypes, HGI, MOL).

Illustrations: Figs. 2 and 3a.

Speciei Telipogon papilio Rchb. fil. Warsz similis, ab ea vero praesertim differens callo conspicuo atque apice columnae setis acuminatis praedito.

Plant caespitose, epiphytic, about $15 \mathrm{~cm}$ tall. Stem to $4 \mathrm{~cm}$, with few basal leaves. Leaves oblanceolate to obovate-lanceolate, acuminate, margin entire, sheath articulated with the blade, $5-8 \times 1.2-2 \mathrm{~cm}$. Inflores- 


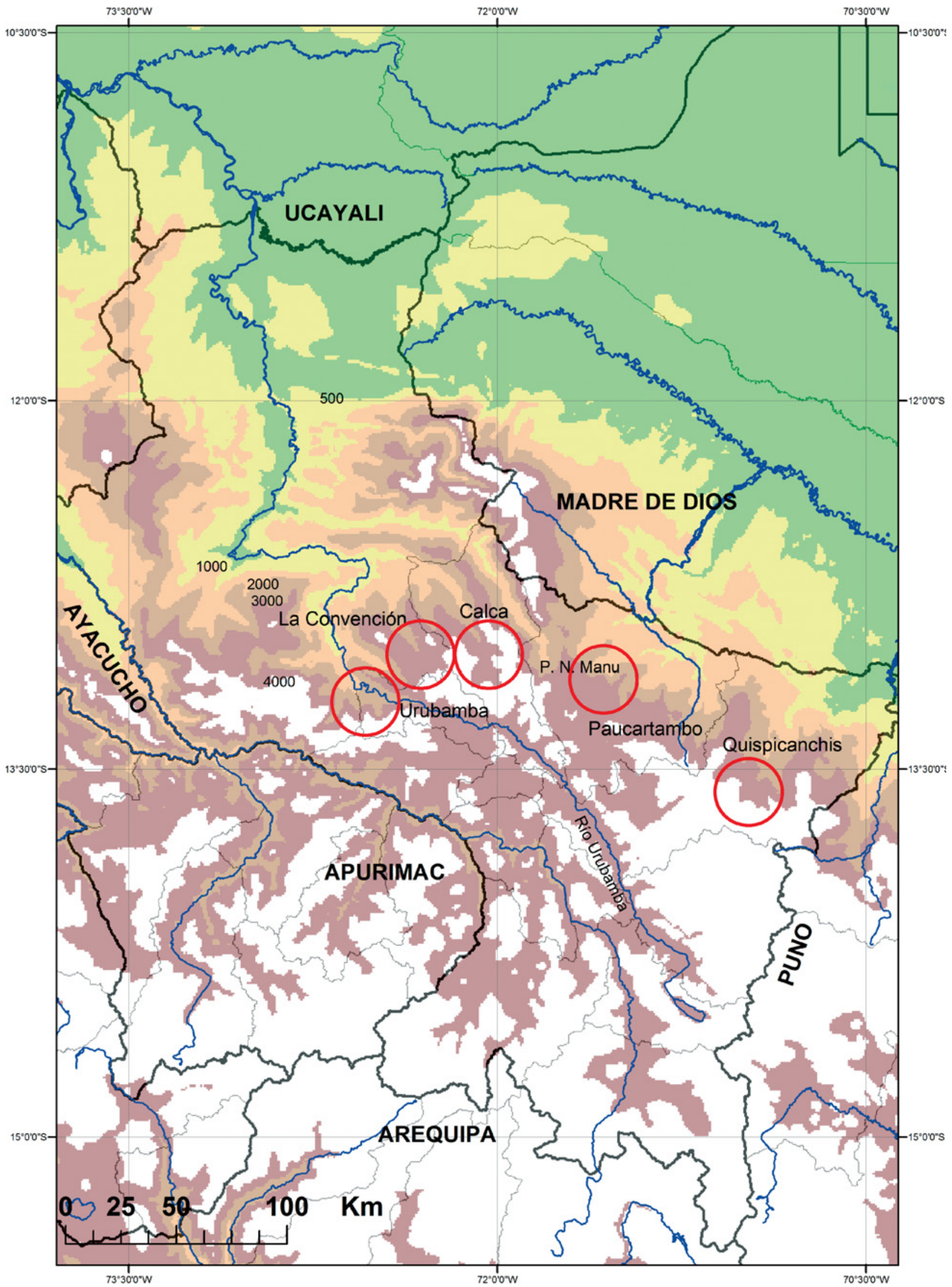

Fig. 1. Map of the oriental valleys of the Department of Cusco. The circles represent the localities where the specimens were collected. 

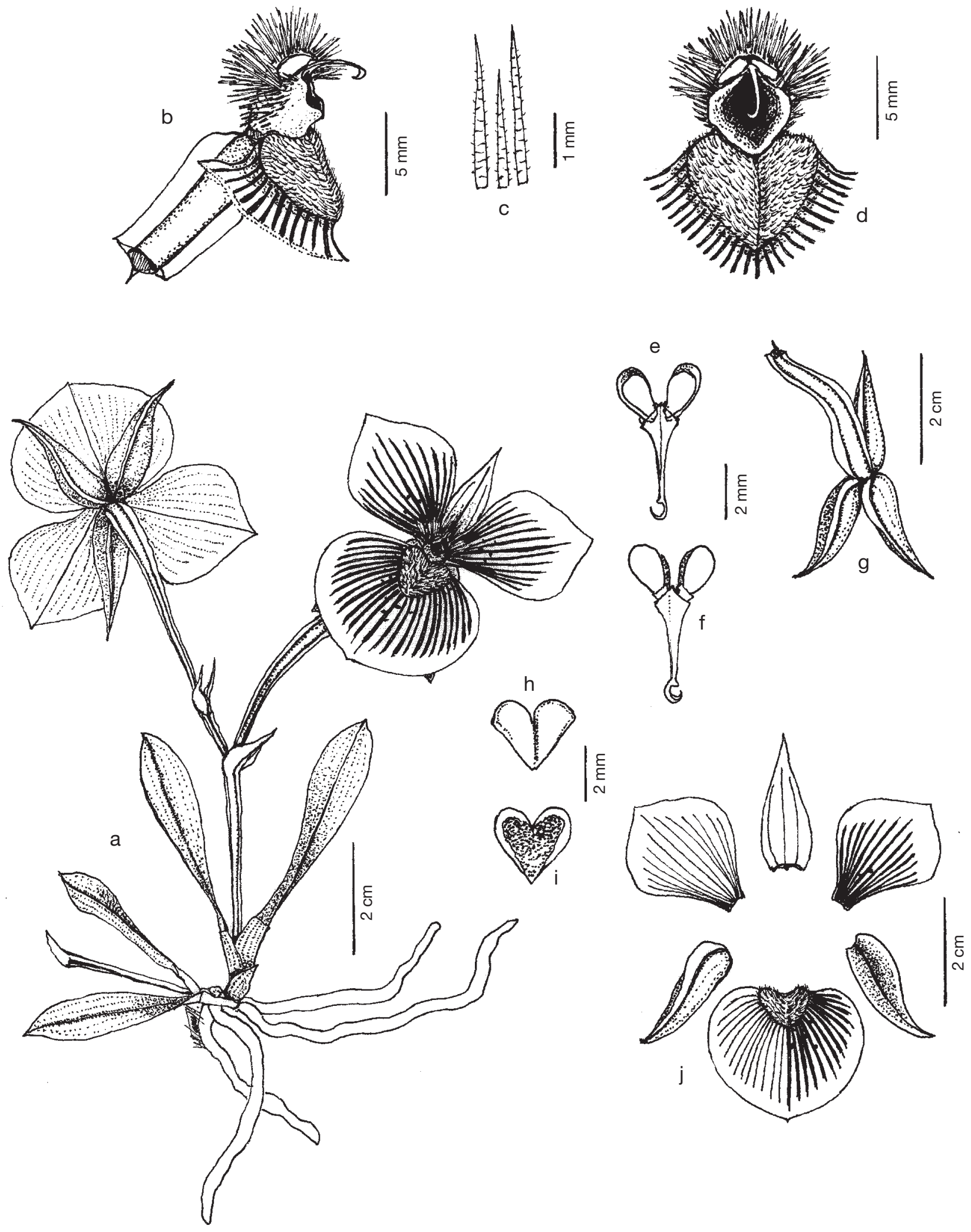

Fig. 2. Telipogon antisuyuensis: a, habit; b, column and callus in lateral view; c, column bristles; d, column and callus in front view; e, pollinarium in dorsal view; $\mathbf{f}$, pollinarium in ventral view; $\mathbf{g}$, ovary and sepals in dorsal view; $\mathbf{h}$, anther in front view; $\mathbf{i}$, anther in ventral view; j, dissected perianth. All drawn from Nauray et al. 3754 (HGI). 

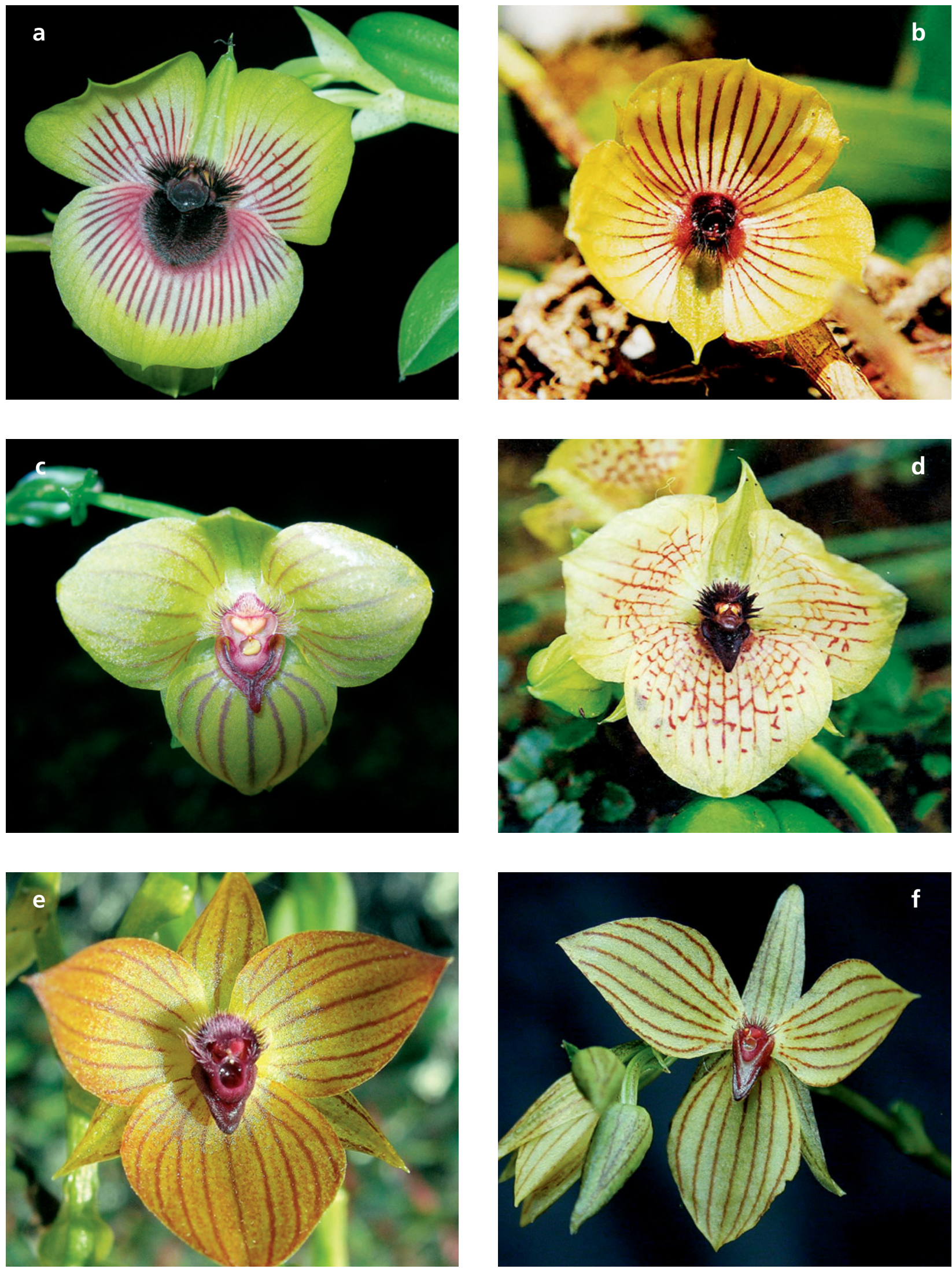

Fig. 3. Flowers of Telipogon: a, T. antisuyuensis; b, T. austroperuvianus; $\mathbf{c}, T$. casadevalliae; d, T. farfanii; e, T. javiercastroviejoi; f, T. kosnipatensis. 
cence and peduncle $5-10 \mathrm{~cm}$ long; peduncle alate, erect or recurved; raceme with 2-4 flowers, usually 12 open at a time; floral bract ovate-triangular, acuminate, dorsally carinate, $1.2 \times 1 \mathrm{~cm}$. Flowers large 4.5-5 $\mathrm{cm}$ in diameter, normally resupinate; pedicellate ovary to $4 \mathrm{~cm}$ long, trialate; sepals $25 \times 10 \mathrm{~mm}$, lime green with dark green veins, ovate-lanceolate, acuminate, dorsally alate, 3 -nerved; petals $25 \times 22 \mathrm{~mm}$, whitish turning lemon yellowish towards the margin with thick longitudinal purple veins and some transversal purple basal veins, broadly obovate-rhombic, obtuse, 13 to15-nerved; lip $25 \times 30 \mathrm{~mm}$, similar in colour to petals, transversely elliptic, obtuse, 23-25-nerved; callus conspicuous, $7 \times 8 \mathrm{~mm}$, dark purple, cordiform, hirsute, completely attached to the lip base. Column $6 \times 6 \mathrm{~mm}$, dark purple, cylindric, with three tufts of bristles surrounding the anther (two lateral and one at the top), the rest of the surface hirsute; bristles to 3.5 $\mathrm{mm}$ long, dark purple, rigid, acuminate, margin microscopically ciliolate; stigma circular or broadly hexagonal; anther $3 \times 3 \mathrm{~mm}$, hyaline, cordiform; stipe to $4 \mathrm{~mm}$ long, hyaline; viscidium $1 \mathrm{~mm}$ long, purple, hyaline, uncinate; pollinia 4, bright yellow, in two dissimilar pairs, ovoid, larger pair $2 \times 1 \mathrm{~mm}$.

Etymology: Named after Antisuyu, the name in Quechua or Runa Simi for the Eastern Andean region of Peru during the Inca Empire.

Distribution and ecology: Telipogon antisuyuensis grows between 2500 and $3400 \mathrm{~m}$ elevation in cloud forests, on Alnus acuminata Kunth (Betulaceae), Baccharis sp. (Asteraceae), Cyathea pallescens Domin (Cyatheaceae), Clusia sp. (Clusiaceae), Hedyosmum sp. (Chloranthaceae), Miconia sp. (Melastomataceae), and Myrsine sp. (Myrsinaceae). It flowers between February and June.

\section{Additional specimens examined (paratypes)}

PERU. Cusco: Urubamba, Huiñay Hayna, 2550 m, 9-III-1944, C. Vargas 4140a (CUZ). Urubamba, Wiñay Wayna, 30-VI-1990, P. Núñez, A. Rodríguez E B. Collantes 12390 (CUZ). Urubamba,

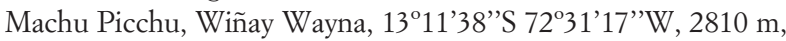
30-III-2007, W. Nauray \& M. Mamani 3757 (CUZ) ibidem, $13^{\circ} 11^{\prime 2} 23^{\prime} \mathrm{S} 72^{\circ} 31$ '10"W, 2654 m, 31-III-2007, W. Nauray \& M. Mamani 3760 (HGI). La Convención, Carrizales, 1306'13'S 72'22'23'W, 3400 m, 11-IV-2007, W. Nauray \& W. Farfán 3762 (CUZ).

Observations: Specimens of this new species have previously been misindentified as T. papilio Rchb. f. \& Warsz. (e.g. Vargas 4140a; Núñez 12390). Examination of the holotype of T. papilio (W!) shows it to be a distinct species that is not currently known from southern Peru. Telipogon antisuyuensis differs from the former in the transverse elliptical lip; the callus conspicuous, cordiform and hirsute, and the column bristles with an acuminate apex. Telipogon antisuyuen- sis is close to T. vasquezii Dodson (holotype SEL!) from Bolivia, but differs in the high number of petal nerves, the larger and transverse lip, and the column bristles not bifid at the apex. Telipogon antisuyuensis is similar to other species of Peru, Ecuador and Colombia but differs in the size of flowers, the nerve number of the petals and the lip, and the presence of callus. Telipogon rhombipetalus C. Schweinf. (holotype F!) has smaller flowers, the petals 15 to16-nerved, and the lip 19-nerved without callus. Telipogon semipictus Rchb. f. ex Kraenzl. (holotype W!) has smaller flowers lacking callus but with the swollen base, the petals 11nerved, and the lip 17-nerved. Telipogon ortizii Dodson \& R. Escobar also lacks a callus and has smaller flowers, and concolorous purple petals, not whitish turning lemon yellowish towards the margin.

Telipogon austroperuvianus Nauray \& A. Galán, sp. nov.

Type: PERU. Cusco: Calca, Lares, Mant'o, 2600 m, Jul. 2001, W. Nauray \& G. Moretz 527 (holotype, CUZ; isotype, HGI).

Illustrations: Fig. 4 and 3b.

Speciei Telipogon semipictus Rchb. fil. ex Kraenzl. similis, ab ea vero praesertim differens floribus maioribus atque labello circiter 13-nervato.

Plant caespitose, epiphytic, about $15 \mathrm{~cm}$ tall. Stem to $3 \mathrm{~cm}$, with few basal leaves. Leaves $9 \times 1.5 \mathrm{~cm}$, oblanceolate, acuminate, margin crenulate, sheath articulated with the blade. Inflorescence and peduncle $12 \mathrm{~cm}$ long; peduncle flexuous, alate; raceme with 2-9 flowers, usually $2-3$ open at a time; floral bract $1.2 \times$ $0.6 \mathrm{~cm}$, ovate-triangular, acuminate, dorsally carinate. Flowers $3-3.5 \mathrm{~cm}$ in diameter, normally resupinate; pedicellate ovary $30-35 \mathrm{~mm}$ long, trialate; sepals $18 \times$ $7 \mathrm{~mm}$, yellowish green, ovate, acuminate, dorsally carinate, 3-nerved; petals $22 \times 20 \mathrm{~mm}$, whitish turning yellow toward the border with longitudinal purplish red veins and some transverse lines in the inferior half, basal surface purplish red, broadly rhombic, acuminate, basal margin denticulate, 9-nerved, basally hirsute; lip $22 \times 26 \mathrm{~mm}$, similar in colour to the petals but longitudinal purplish red veins wider and longer, transversely obovate, acuminate, basal margin denticulate, 13-nerved, hirsute, swollen in the base. Column $4 \times 4 \mathrm{~mm}$, dark purple, cylindric, with three tufts of bristles around the anther (two lateral and one on top); bristles to $3 \mathrm{~mm}$ long, dark purple, flexuous, acuminate or caudate apically; stigma circular; anther $2 \times 2.5 \mathrm{~mm}$, hyaline purple, cordiform; stipe $3 \mathrm{~mm}$ long, hyaline purple; viscidium $1 \mathrm{~mm}$ long, uncinate; pollinia 4 , bright yellow, in two dissimilar pairs, ovoid, larger pair $1.4 \times 0.7 \mathrm{~mm}$.

Etymology: The name refers to southern Peru. 


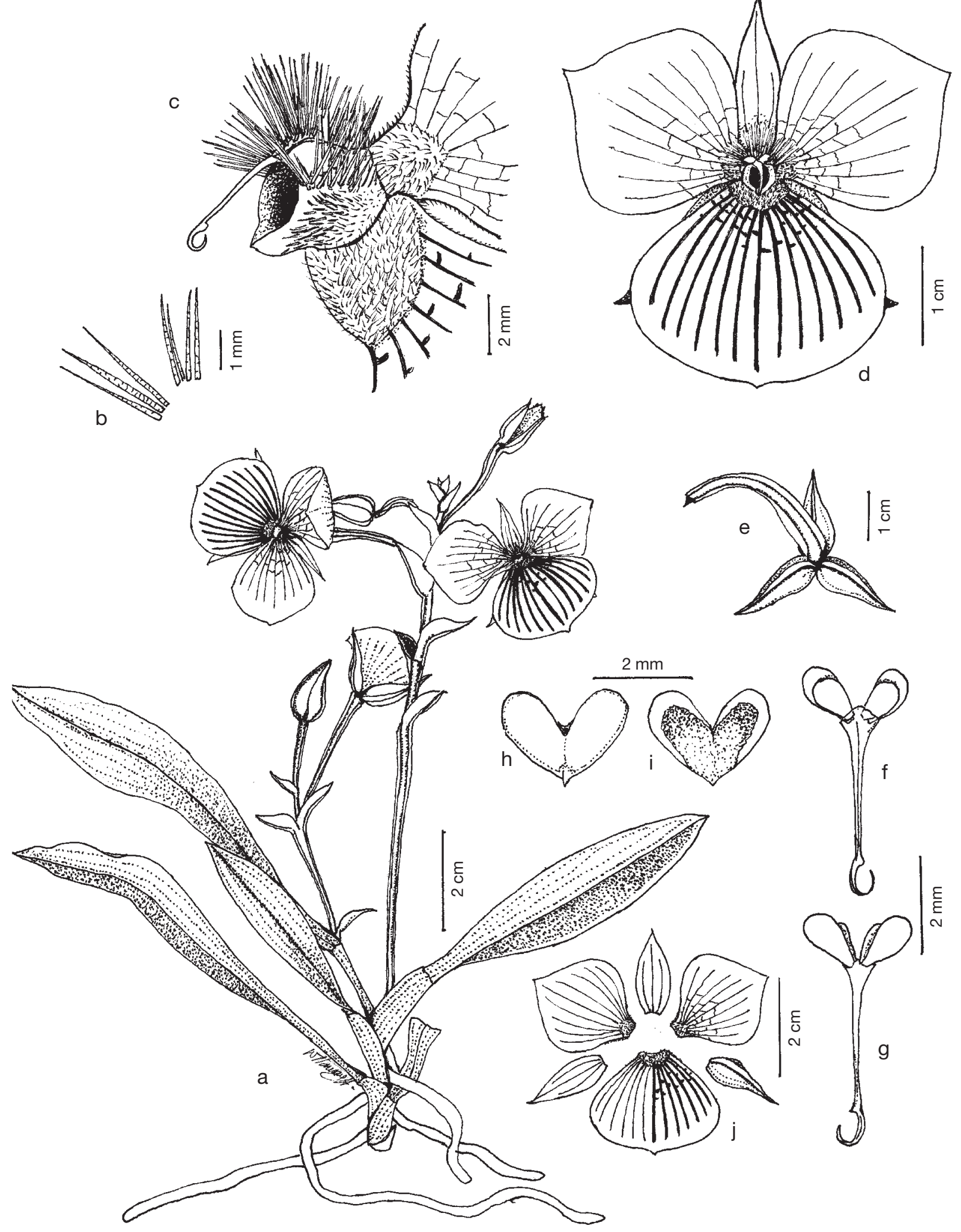

Fig. 4. Telipogon austroperuvianus: $\mathbf{a}$, habit; $\mathbf{b}$, column bristles; $\mathbf{c}$, column and base lip in lateral view; $\mathbf{d}$, flower in front view; e, ovary and sepals in dorsal view; f, pollinarium in dorsal view; $\mathbf{g}$, pollinarium in ventral view; $\mathbf{h}$, anther in front view; $\mathbf{i}$, anther in ventral view; j, dissected perianth. All drawn from Nauray 527 \& G. Moretz (HGI). 
Distribution and ecology: Telipogon austroperuvianus is found in cloud forest at $2600 \mathrm{~m}$; it flowers between March and July.

\section{Additional specimens examined (paratypes)}

PERU. Cusco: La Convención, Quellomayo-Lucumayo, 2450 m, 26-VII-1944, Vargas 4540 (CUZ). Calca, Lares, Mant'o, Km 84, 2040 m, 19-VI-1964, Vargas 15618 (CUZ). Calca, Lares, Valle de Lares, Mant'o, 2100 m, III-2002, W. Farfán E G. Moretz 277 (CUZ).

Observations: Telipogon austroperuvianus is distinguished by the petals which are broadly rhombic, 9nerved, and the lip transversely obovate, and 13 nerved. It is similar to some species from northern South America, such as T. semipictus from Colombia and T. andicola Rchb. f. from Colombia, Ecuador and Venezuela (holotype W!, isotype K!). The specimens cited above have been misidentified as T. semipictus, but examination of the holotype (W!) shows it to be a distinct species from which this new species differs in its larger flowers, fewer nerves on the petals and lip, and the lip with longer and thicker red purplish veins. From $T$. andicola it differs in its larger flowers, more nerves on the petals and the lip, and the coloured veins of the petals that do not reach the distal half. Telipogon austroperuvianus is also related to the Ecuadorian T. lehmannii Schltr. (lectotype K!), but it differs in the size of the flowers and the characters from the petals, and the lip. According to Schlechter (1920) T. lebmannii has petals $1.7 \times 1.4 \mathrm{~cm}, 11$ nerved, and the lip $1.65 \times 1.8 \mathrm{~cm}, 19$-nerved.

Telipogon casadevalliae Nauray, A. Galán \& M. Mamani, sp. nov.

Type: PERU. Cusco: Paucartambo, Kosñipata, Trocha Unión, Parque Nacional del Manu, 13 ${ }^{\circ}$ 06' 29" S, 71 35' 35" W, 2800 m, 24 Jan. 2007, M. Mamani 867 (holotype, CUZ; isotypes, HGI, MOL).

Illustrations: Fig. 5 and 3c.

Speciei Telipogon machupicchuensis Nauray \& Christenson similis, ab ea vero praesertim differens labello late ovato, callo convexo, carinato, et columna setis longis atque recurvatis praedita.

Plant caulescent, terrestrial or epiphytic, about 30 $\mathrm{cm}$ tall. Stem $20 \mathrm{~cm}$ long, erect, leafy throughout. Leaves $4 \times 1 \mathrm{~cm}$, ovate-lanceolate to oblanceolate, acuminate, margin ciliolate, sheath not articulated with the blade. Inflorescence and peduncle to $15 \mathrm{~cm}$ long; peduncle angled, flexuous; raceme with 3-6 flowers, usually one open at a time; floral bract ovatetriangular, acuminate, conduplicate, $1.1 \times 0.6 \mathrm{~cm}$. Flowers $2-2.5 \mathrm{~cm}$ in diameter, normally not resupinate; pedicellate ovary tricarinate, $8-10 \mathrm{~mm}$ long; sepals $11 \times 5 \mathrm{~mm}$, lime green with dark lime green veins, ovate, apiculate, concave, 3 -nerved; petals $15 \times$
$11 \mathrm{~mm}$, golden yellow with longitudinal purple veins, broadly ovate, acute, basal margin ciliolate, 7 -nerved; lip $15 \times 12 \mathrm{~mm}$, similar in colour to the petals, broadly ovate, obtuse, basal margin ciliolate, 7-nerved; callus $5 \times 4 \mathrm{~mm}$, purple, broadly Y- shaped, velutinous, convex, with a narrow Y-shaped ridge, the apical half free from the lip. Column 2.5-3 × 3-4 mm, purple, with two lateral tufts of bristles and hirsute on top; bristles to $2 \mathrm{~mm}$ long, pale purple, recurved, acuminate or caudate apically; stigma quadrangular; anther $1.5 \times 2 \mathrm{~mm}$, purple hyaline, cordiform; stipe to 1.2 $\mathrm{mm}$ long, purple hyaline; viscidium $0.6 \mathrm{~mm}$ long, orange hyaline, uncinate; pollinia 4 , bright yellow, in two dissimilar pairs, ovoid, larger pair $1.2 \times 0.2 \mathrm{~mm}$.

Etymology: Named in honor of Dr. Margarida Casadevall Masso, Professor at the University of Gerona.

Distribution and ecology: Telipogon casadevalliae grows between 2700 and $3000 \mathrm{~m}$ elevation in cloud forests, on Prunus sp. (Rosaceae), Weinmannia bangii Rusby and W. microphylla Kunth (Cunoniaceae). It flowers between January and March.

\section{Additional specimen examined (paratype)}

PERU. Cusco: Paucartambo, Pillahuata, Manu Biosphere Reserve, 3000 m, III-2000, W. Farfán 197 (CUZ).

Observations: Telipogon casadevalliae is close to T. machupicchuensis Nauray \& Christenson (holotype CUZ!) but differs to the lip broadly ovate, the convex, Y-shaped, keeled callus, and the column with two lateral tufts of recurved bristles.

Telipogon farfanii Nauray \& A. Galán, sp. nov.

Type: PERU. Cusco: Urubamba, Machu Picchu, Mesada, 3450 m, 12 Mar. 2002, N. Salinas, W. Farfán, K. García E E. Gutiérrez MP-110 (holotype, CUZ).

Illustrations: Fig. 6 and 3 d.

Speciei Telipogon tessellatus Lindl. similis, ab ea vero praesertim differens callo convexo et agittato stigmateque trilobo.

Plant caespitose, scrambling, epiphytic, about 20 $\mathrm{cm}$ tall. Stem to $5 \mathrm{~cm}$, with few basal leaves. Leaves 6$11 \times 1.5 \mathrm{~cm}$, oblanceolate to lanceolate, acuminate, sheath articulated with the blade. Inflorescence and peduncle to $10 \mathrm{~cm}$ long; the peduncle compressed, alate, erect to recurved; raceme with 1-3 flowers, usually one open at a time; floral bract $1.8 \times 0.8 \mathrm{~cm}$, ovatetriangular, acuminate, dorsally carinate. Flowers 4-5.3 $\mathrm{cm}$ in diameter, resupinate; pedicellate ovary $5 \mathrm{~cm}$ long, trialate; sepals $22 \times 10 \mathrm{~mm}$, translucent lime green with dark lime green veins, ovate, acuminate, dorsally keeled, 3-nerved; petals $25 \times 20 \mathrm{~mm}$, cream yellow, with pale purple reticulated veins becoming 


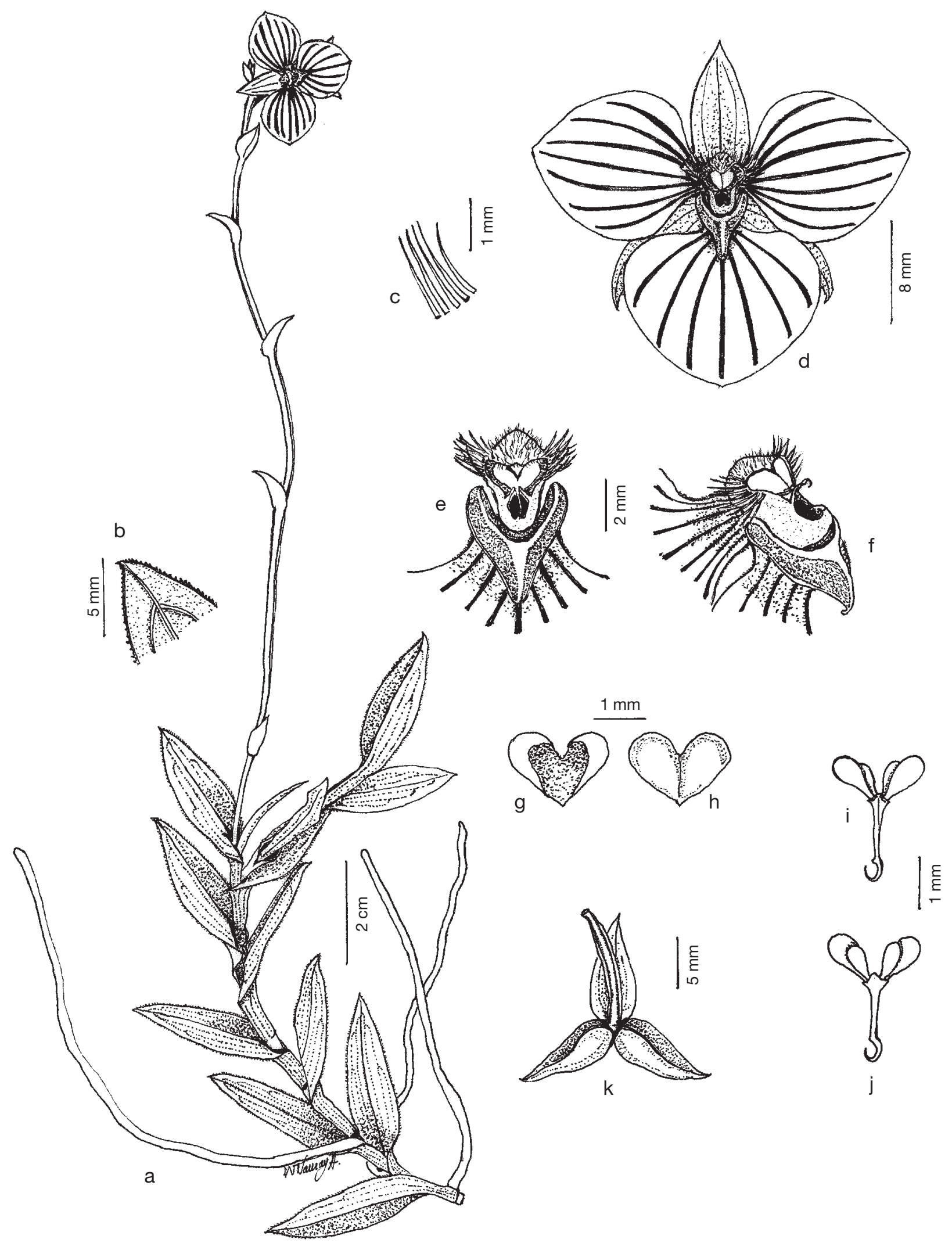

Fig. 5. Telipogon casadevalliae: a, habit; $\mathbf{b}$, leaf apex; c, column bristles; $\mathbf{d}$, flower in front view; e, column and callus in front view; $\mathbf{f}$, column and callus in lateral view; $\mathbf{g}$, anther in ventral view; $\mathbf{h}$, anther in dorsal view; i, pollinarium in dorsal view; j, pollinarium in ventral view; k, ovary and sepals in dorsal view. All drawn from Mamani 867 (HGI). 


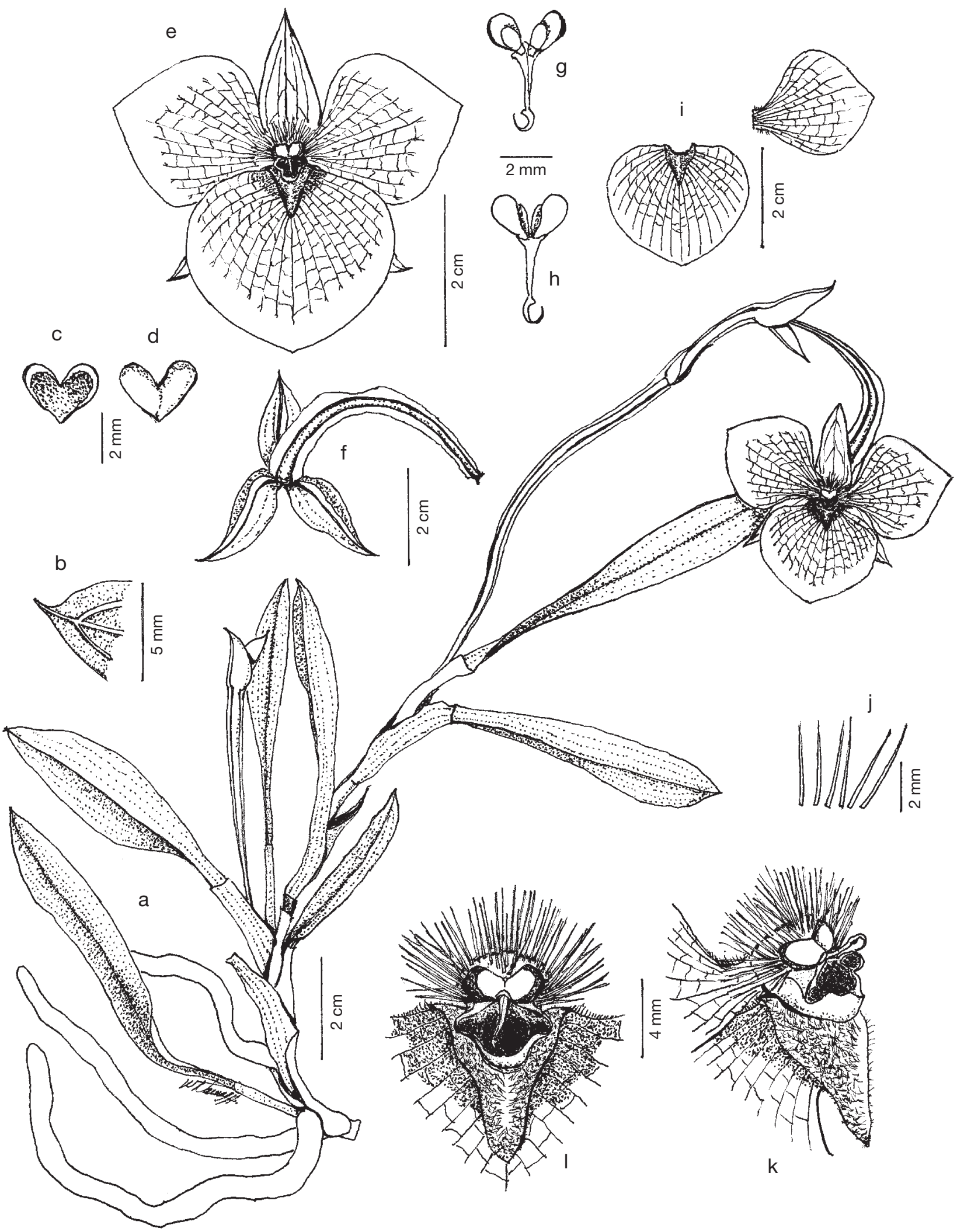

Fig. 6. Telipogon farfanii: a, habit; $\mathbf{b}$, leaf apex; $\mathbf{c}$, anther in ventral view; d, anther in dorsal view; e, flower in front view; $\mathbf{f}$, ovary and sepals in dorsal view; $\mathbf{g}$, pollinarium in dorsal view; $\mathbf{h}$, pollinarium in front view; i, separate petals and lip; j, column bristles; $\mathbf{k}$, column and callus in lateral view; I, column and callus in front view. All drawn from Moscoso et al. MP-33 (HGI). 
colorless toward the margin, broadly rhombic, acute, basal margin ciliolate, 11 to13-nerved also with cross veins in the basal half; lip $25 \times 28 \mathrm{~mm}$, similar in colour to the petals and with an irregular purple spot under the callus, subcircular, obtuse, basal margin ciliolate, 19 to 21-nerved with cross veins in the basal half; callus $8 \times 6 \mathrm{~mm}$, dark purple, sagittate, hirsute, convex in the front, the apical half free from the lip. Column $3 \times 5 \mathrm{~mm}$, dark purple, with three ill-differentiated groups of bristles; bristles to $3.5 \mathrm{~mm}$ long, dark purple, rigid, acuminate or cuadate apically; stigma trilobulate, lateral lobes auriculate and mid lobe circular; anther $2.5 \times 3 \mathrm{~mm}$, hyaline purple, cordiform; stipe to $2.5 \mathrm{~mm}$ long, hyaline; viscidium $0.8 \mathrm{~mm}$ long, uncinate; pollinia 4 , bright yellow, in two dissimilar pairs, ovoid, larger pair $2 \times 0.9 \mathrm{~mm}$.

Etymology: Named in honor of William Farfán Ríos, biologist of the Universidad San Antonio Abad del Cusco, scientific researcher of Peruvian orchids.

Distribution and ecology: Telipogon farfanii grows between 3450 and $3500 \mathrm{~m}$ elevation in cloud forests, on Polylepis pauta Hieron (Rosaceae) where it flowers between March and July.

\section{Additional specimen examined (paratype)}

PERU. Cusco: Urubamba, Machu Picchu, Incatambo, 3500 m, VII-2001, D. Moscoso, N. Salinas, W. Nauray, W. Farfán, C. Uchima E E. Gutiérrez MP-33 (HGI).

Observations: Telipogon farfanii differs from T. tessellatus Lindl. (holotype K!) in its larger flowers, and sagittate and convex callus. In T. tessellatus, the petals are ca. $1.2 \times 1.2 \mathrm{~cm}$, the lip ca. $1.2 \times 2 \mathrm{~cm}$, and the callus is pad-shaped. Telipogon farfanii is similar to the Ecuadorian species T. jimburensis Dodson \& R. Escobar but is distinguished by the form of the callus and stigma. Telipogon jimburensis has a trilobed callus, and unlobed stigma; in addition, the column has an upturned apicule under the stigma. Telipogon octavioi Dodson \& R. Escobar is similar to T. farfanii, but this species from Colombia and Ecuador has smaller flowers, the petals 9-nerved, the lip 11 to 13 -nerved, and a tongue-like callus.

Telipogon javiercastroviejoi Nauray \& A. Galán, sp. nov.

Type: PERU. Cusco: Paucartambo, Kosñipata, Acjanaco-Tres Cruces, Manu National Park, $13^{\circ} 09^{\prime} 47^{\prime \prime}$ S, 71³2' 00" W, 3491 m, 25 Apr. 2007, W. Nauray E M. Mamani 3767 (holotype, CUZ; isotypes, HGI, MOL).

Illustrations: Fig. 7 and 3e.

Speciebus Telipogon benedicti Rchb. fil. atque Telipogon boissierianus Rchb. fil. similis, a prima vero praesertim differens columna et setis eius brevioribus, a secunda item differens labello et lateralibus petalis non reticularis.

Plant caulescent, terrestrial, about $30 \mathrm{~cm}$ tall. Stem $20 \mathrm{~cm}$ long, erect, leafy throughout. Leaves $2.5 \times 0.8$ $\mathrm{cm}$, oblong, acute to emarginate, sheath not articulated with the blade. Inflorescence and peduncle 5-15 $\mathrm{cm}$ long; peduncle cylindrical to lightly trigonous, erect; raceme with 2-7 flowers, usually 1-2 open at a time; floral bract $0.7 \times 0.6 \mathrm{~cm}$, ovate-triangular, acuminate. Flowers $1.5-2 \mathrm{~cm}$ in diameter, normally not resupinate; pedicellate ovary $18 \mathrm{~mm}$ long, cylindrical to trigonous; sepals $8 \times 4 \mathrm{~mm}$, yellowish green with purple veins and purple apical dots, ovate, acuminate, dorsally carinate, 3 -nerved; petals $12 \times 8$ $\mathrm{mm}$, yellow with longitudinal veins and many purple dots, broadly ovate, acuminate, basal margin ciliolate, 7-nerved; lip $12 \times 10 \mathrm{~mm}$, similar in colour to the petals, broadly ovate, acuminate, basal margin ciliolate, 9-nerved; callus $3 \times 3 \mathrm{~mm}$, purple, sagittate, velutinous, convex in the front, dorso-ventrally split in the apex, the apical half free from the lip. Column $2 \times$ $3 \mathrm{~mm}$, purple, crowned in front by bristles; bristles to $1 \mathrm{~mm}$ long, pale purple, recurved, acuminate or caudate apically; stigma quadrangular; anther $0.8 \times 1$ $\mathrm{mm}$, hyaline purple, cordiform; stipe $0.5 \mathrm{~mm}$ long, hyaline purple; viscidium $0.2 \mathrm{~mm}$ long, hyaline purple, uncinate; pollinia 4, bright yellow, in two dissimilar pairs, ovoid, larger pair $0.7 \times 0.4 \mathrm{~mm}$. Fruits $17 \times 7$ $\mathrm{mm}$, tricarinate, dehiscent along three longitudinal lines.

Etymology: Named in honor of Dr. Javier Castroviejo Bolibar, from Asociación Amigos del Coto de Doñana, Seville, promoter of the cooperation in biodiversity research between Spain and Latin America.

Distribution and ecology: T. javiercastroviejoi grows in the limit between the elfin forests and the humid Puna (3000-3500 m). It flowers between April and July.

\section{Additional specimen examined (paratype)}

PERU. Cusco: Paucartambo, Kosñipata, Tres Cruces, 3000 m, VII-2002, W. Farfán 59 (CUZ, MA).

Observations: Telipogon javiercastroviejoi is distinguished by the callus apex dorso-ventrally split, a good morphological feature that is in contrast to other caulescent species. It differs from the Bolivian species T. benedicti Rchb. f. (holotype W!) in its shorter column and bristles, and from T. boissierianus Rchb.f. (holotype G!) with its larger leaves, the smaller flowers, and the absence of reticulated purple veins from the petals and the lip. Telipogon javiercastroviejoi is similar to the Colombian and Ecuadorian T. venustus Schltr., from which it mainly differs in the characters of the callus and the column. In T. venustus, the 


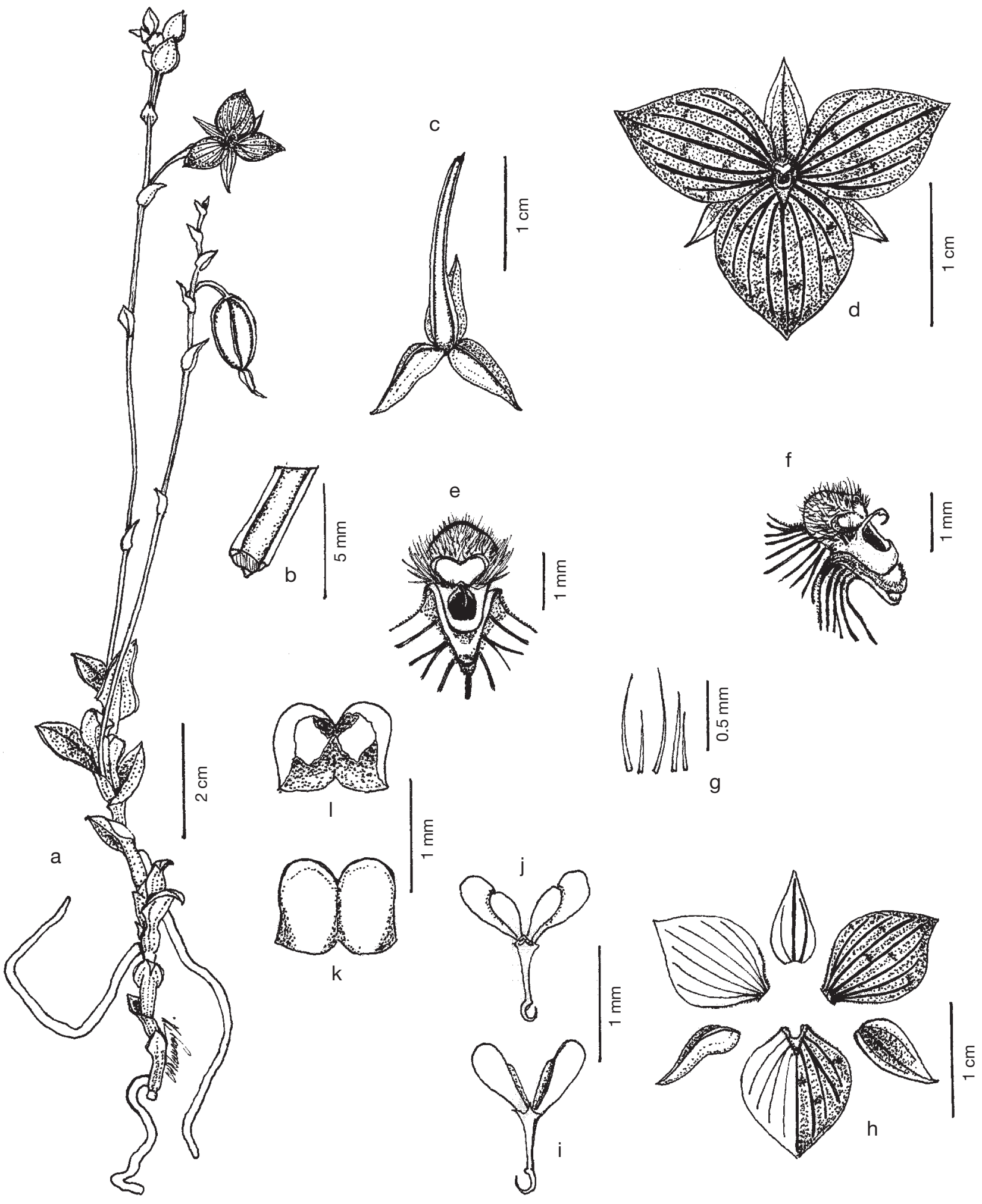

Fig. 7. Telipogon javiercastroviejoi: a, habit; $\mathbf{b}$, section of peduncle; $\mathbf{c}$, ovary and sepals in dorsal view; $\mathbf{d}$, flower in front view; e, column and callus in front view; $\mathbf{f}$, column and callus in lateral view; $\mathbf{g}$, column bristles; $\mathbf{h}$, dissected perianth; i, pollinarium in ventral view; j, pollinarium in dorsal view; k, anther in dorsal view; l, anther in ventral view. All drawn from Nauray \& Mamani 3767 (HGI). 
callus is glabrous, the column is completely bald, and the lip is obovate (Schlechter, 1920). We were not able to study an additional voucher determined as $T$. venustus from Cusco, collected by Núñez 7710 and deposited at MO; we believe that because of the geographic distance this species is not found in southern Peru, and that this specimen may also be T. javiercastroviejoi.

Telipogon kosnipatensis Farfán, Nauray \& A. Galán, sp. nov.

Type: PERU. Cusco: Paucartambo, Kosñipata, Acjanaco-Tres Cruces, Manu National Park, $13^{\circ} 09^{\prime} 47^{\prime \prime}$ S, 71 32' 00" W, 3491 m, 25 Apr. 2007, W. Nauray \& M. Mamani 3767 (holotype, CUZ; isotypes, HGI, MOL).

Illustrations: Fig. 8 and $3 f$.

Speciei Telipogon machupicchuensis Nauray similis, ab ea vero praesertim differens callo sagittato columnaeque setis longioribus.

Plant caulescent, epiphytic, about $22 \mathrm{~cm}$ tall. Stem $15 \mathrm{~cm}$ long, leafy throughout. Leaves $4 \times 0.8 \mathrm{~cm}$, oblanceolate, acute to acuminate, margins fimbriate, sheath not articulated with the blade. Inflorescence and peduncle $10 \mathrm{~cm}$ long; peduncle sulcate, recurved; raceme with 4-8 flowers, usually two open at a time; floral bract $0.7 \times 0.3 \mathrm{~cm}$, ovate-triangular, acuminate, dorsally carinate. Flowers $2.5-2.8 \mathrm{~cm}$ in diameter, normally not resupinate; pedicellate ovary $15 \mathrm{~mm}$ long, tricarinate; sepals $12 \times 5 \mathrm{~mm}$, translucent cream yellow with brown reddish veins, ovatelanceolate, acuminate, 3-nerved; petals $18 \times 10 \mathrm{~mm}$, cream yellow with reddish brown longitudinal veins, elliptic, acuminate, basal margin ciliolate, 7 -nerved; lip $18 \times 13 \mathrm{~mm}$, similar in colour to the petals, broadly elliptic acuminate, basal margin ciliolate, 7 -nerved; callus $6 \times 4 \mathrm{~mm}$, purple, sagittate, pubescent, with a sagittate plateau on top, the apical half free from the lip. Column $2 \times 2 \mathrm{~mm}$, purple, crowned in front by bristles, the rest of the surface finely pilose; bristles to $1.5 \mathrm{~mm}$ long, purple, recurved, acuminate or caudate apically; stigma circular; anther $1.5 \times 1.5 \mathrm{~mm}$, hyaline purple, cordiform; stipe to $1.5 \mathrm{~mm}$ long, hyaline; viscidium $0.5 \mathrm{~mm}$ long, uncinate; pollinia 4 , bright yellow, in two dissimilar pairs, ovoid, larger pair $1.2 \times$ $0.6 \mathrm{~mm}$.

Etymology: Named after the type locality, Kosñipata District in Cusco.

Distribution and ecology: Telipogon kosnipatensis is found in cloud forest (3000-3500) with Weinmannia spp. (Cunoniaceae). It flowers in November.

\section{Additional specimen examined (paratype)}

PERU. Cusco: Paucartambo, Kosñipata, Trocha Unión, Manu
National Park, 3000 m, XI-2006, M. Mamani s.n. (photograph, flower in alcohol, HGI).

Observations: Telipogon kosnipatensis is similar to T. machupicchuensis Nauray \& Christenson (holotype CUZ!). In T. kosnipatensis, the callus is sagittate with a sagittate plateau, and the column has longer recurved bristles.

Telipogon marleneae Nauray \& A. Galán, sp. nov.

Type: PERU. Cusco: La Convención, Carrizales, $13^{\circ} 06^{\prime} 46^{\prime} \mathrm{S}, 72^{\circ} 21^{\prime} 31^{\prime}$ W, $3550 \mathrm{~m}, 11$ Apr. 2007, W. Nauray \& W. Farfán 3761 (holotype, CUZ; isotypes, HGI, MA, MOL).

Illustrations: Fig. 9 and 10a.

Speciei Telipogon tessellatus Lindl. similis, ab ea vero praesertim differens labello emarginato, callo trilobo columnaque setarum tribus fasciculis praedita.

Plant caespitose, epiphytic, about $23 \mathrm{~cm}$ tall. Stem to $4 \mathrm{~cm}$, with few basal leaves. Leaves $9 \times 2 \mathrm{~cm}$, oblanceolate to obovate-lanceolate, acute, sheath articulated with the blade. Inflorescence and peduncle to $12 \mathrm{~cm}$ long; the peduncle, alate, erect; raceme with 2-5 flowers, usually 2-4 open at a time; floral bract 1.5 $\times 1.2 \mathrm{~cm}$, ovate-triangular, acuminate, dorsally carinate. Flowers $3.5-4.5 \mathrm{~cm}$ in diameter, normally resupinate; pedicellate ovary $35-40 \mathrm{~mm}$ long, trialate; sepals $20 \times 10 \mathrm{~mm}$, translucent yellowish green with longitudinal purple veins and oblique purple lines, ovate, acuminate, dorsally keeled, 3-nerved; petals 22 $\times 22 \mathrm{~mm}$, yellow, with purple reticulated veins colourless toward the margin, broadly rhombic, acute, 9nerved also cross-sectional nerves; lip $22 \times 28-30 \mathrm{~mm}$, yellow, similar in colour to the petals, transversely elliptic, emarginate, 17 -nerved and with cross nerves; callus $8 \times 7 \mathrm{~mm}$, dark purple, trilobulate, lateral lobes quadrangular and mid lobe ovate-triangular, sharply convex, hispid, the apical half free from the lip. Column, $3 \times 4 \mathrm{~mm}$, dark purple, with three tufts of bristles (two lateral and one at the top) and the rest of the surface pubescent; bristles to $3.5 \mathrm{~mm}$ long, dark purple, rigid, acuminate or caudate apically; stigma trapezoidal; anther $1.5 \times 2 \mathrm{~mm}$, translucent purple, cordiform; stipe $1.5 \mathrm{~mm}$ long, hyaline; viscidium $0.7 \mathrm{~mm}$ long, purple hyaline, uncinate; pollinia 4, bright yellow, in two dissimilar pairs, ovoid, larger pair $1.5 \times 0.7$ $\mathrm{mm}$.

Etymology: Named in honor of Marlene Mamani Solorzano, botanist of the Universidad Nacional San Antonio Abad del Cusco, scientific researcher of the Peruvian flora and vegetation.

Distribution and ecology: Telipogon marleneae is found in cloud forest $(3550 \mathrm{~m})$ on Polylepis pauta Hieron. (Rosaceae). It flowers in April. 


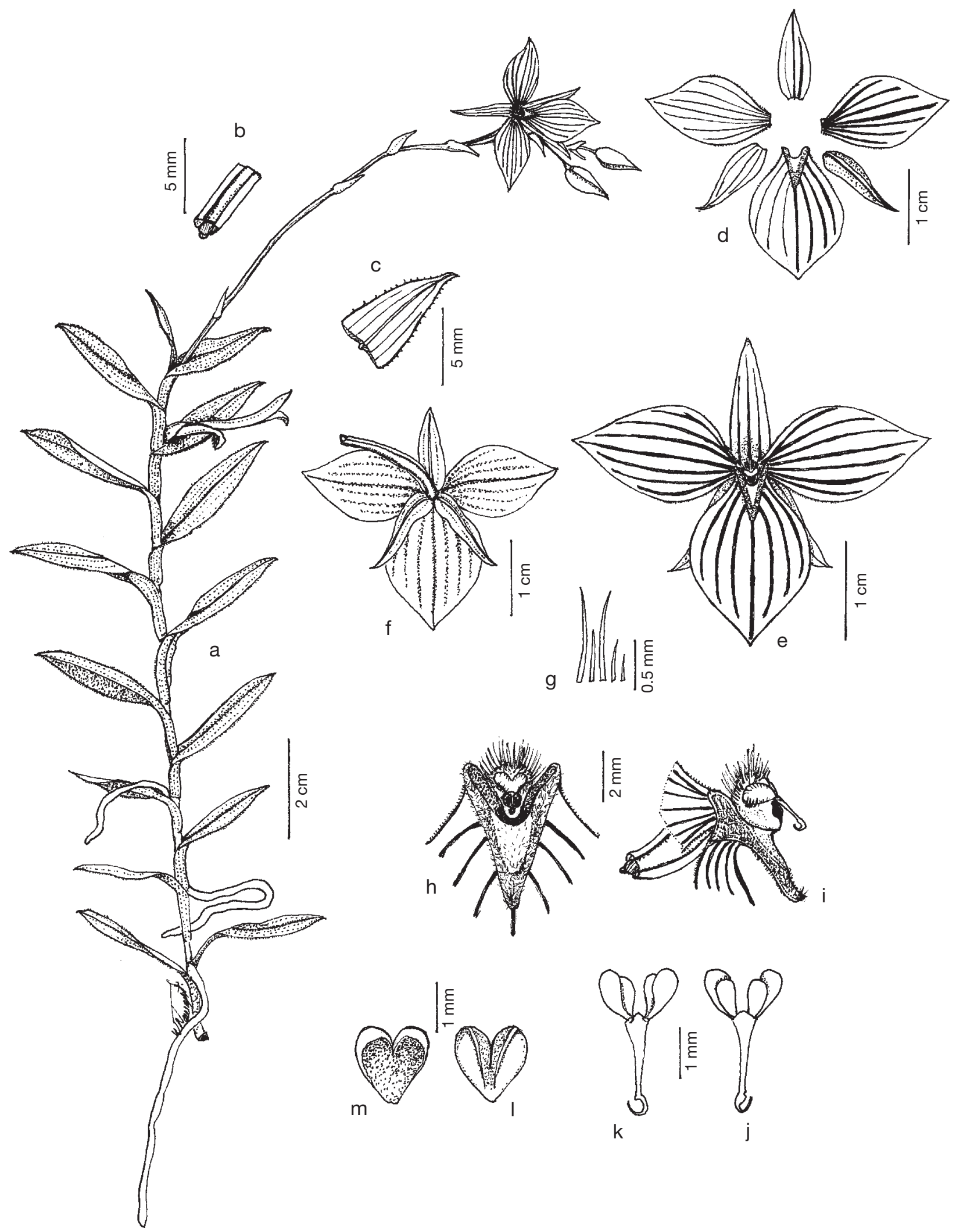

Fig. 8. Telipogon kosnipatensis: $\mathbf{a}$, habit; $\mathbf{b}$, section of peduncle; $\mathbf{c}$, leaf apex; $\mathbf{d}$, dissected perianth; e, flower in front view; f, flower in dorsal view; g, column bristles; $\mathbf{h}$, column and callus in front view; i, column and callus in lateral view; j, pollinarium in dorsal view; $\mathbf{k}$, pollinarium in front view; l, anther in front view; m, anther in ventral view. All drawn from Farfán TU-09 (HGI). 


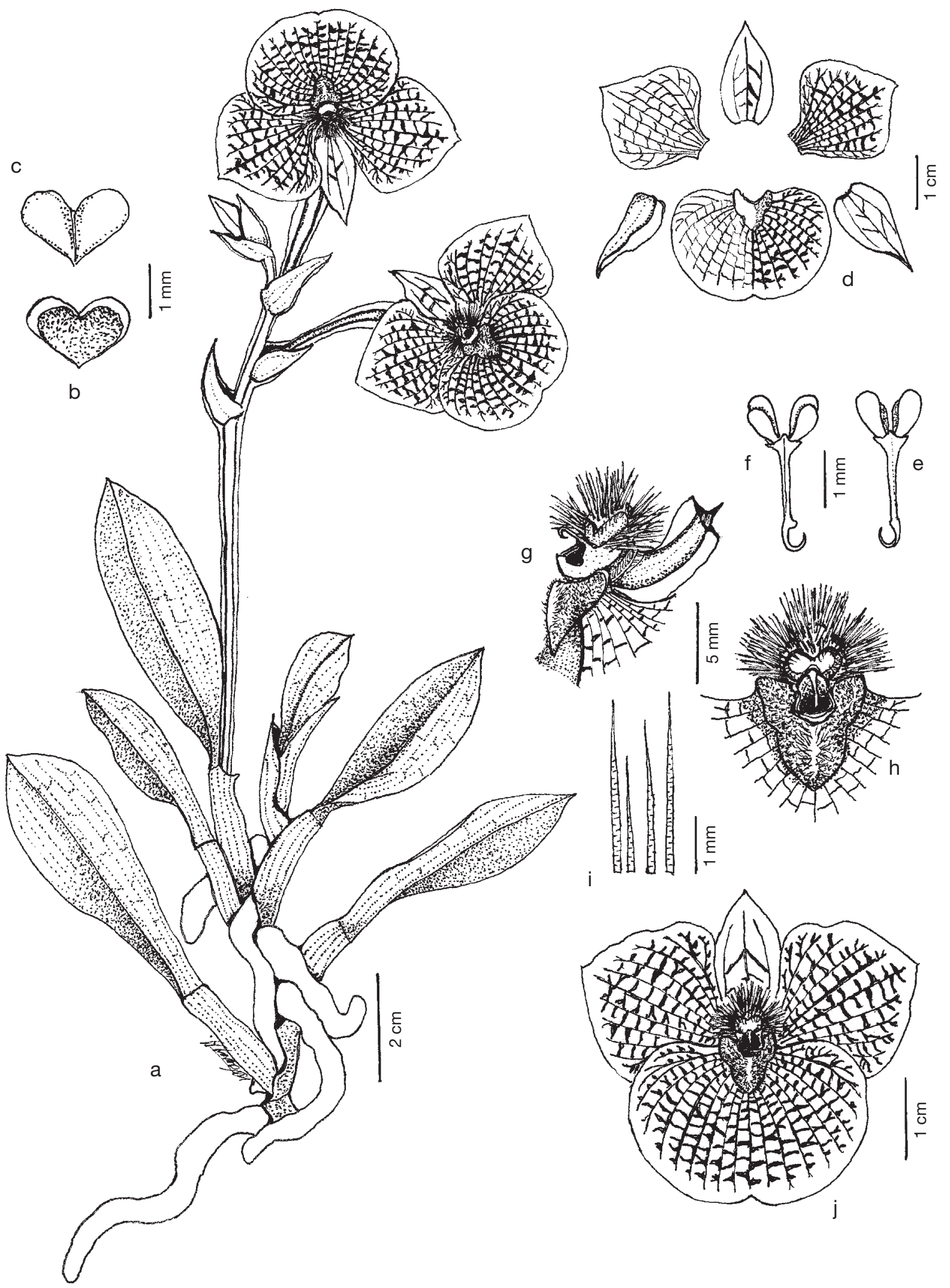

Fig. 9. Telipogon marleneae: $\mathbf{a}$, habit; $\mathbf{b}$, anther in ventral view; $\mathbf{c}$, anther in front view; $\mathbf{d}$, dissected perianth; e, pollinarium in front view; f, pollinarium in ventral view; $\mathbf{g}$, column and callus in lateral view; $\mathbf{h}$, column and callus in front view; i, column bristles; j, flower in front view. All drawn from Nauray 3761 \& Farfán (HGI). 

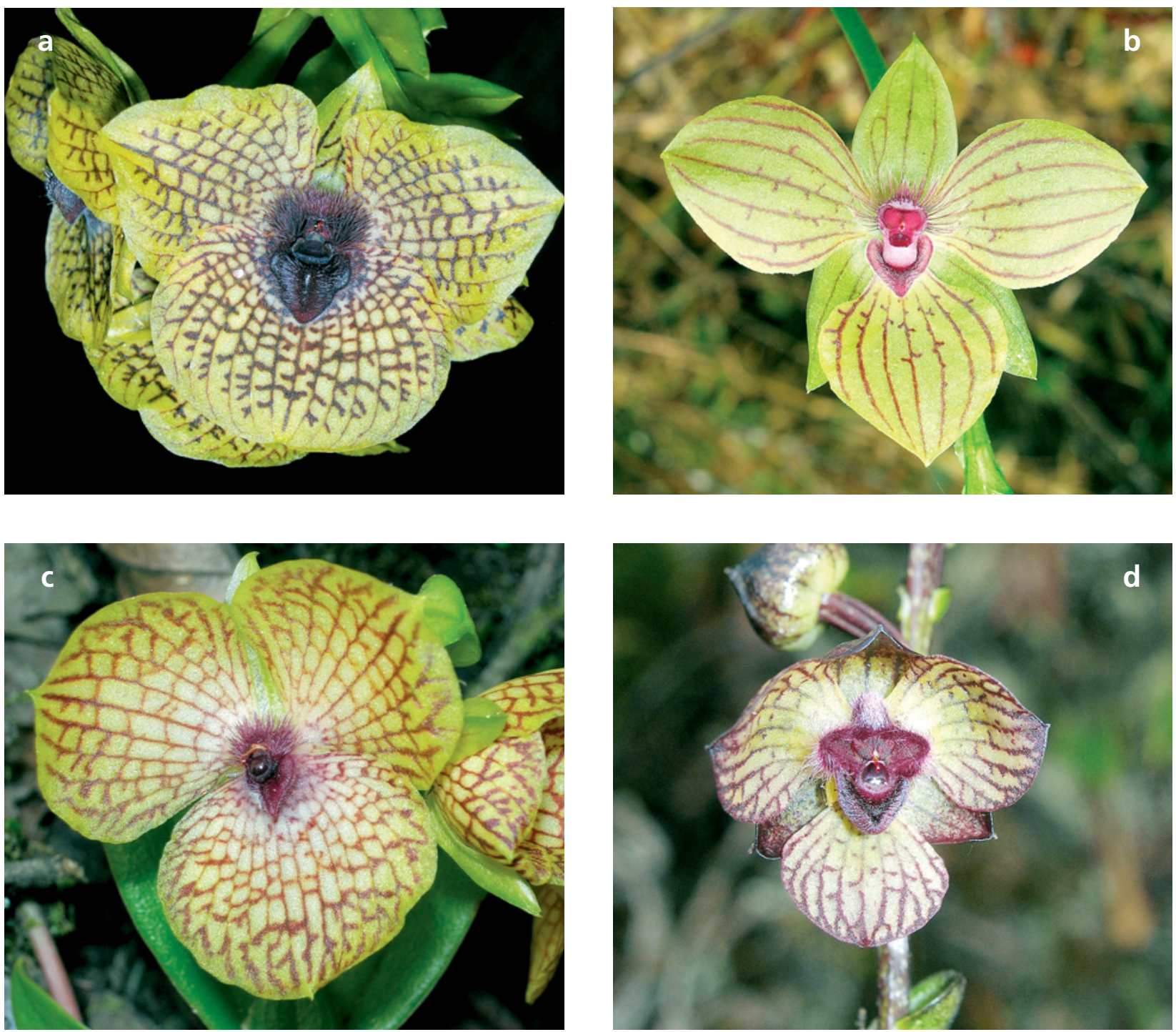

Fig. 10. Flowers of Telipogon: a, T. marleneae; b, T. mesotropicalis; c, T. santiagocastroviejoi; d, T. tupayachii.

Observations: Telipogon marleneae is similar to Andean species with reticulated veins in the petals and the lip. It differs from the Ecuadorian T. tessellatus Lindl. (holotype $\mathrm{K}$ !) in the emarginate lip, the callus trilobed and sharply convex, and the column with three tufts of bristles. Telipogon marleneae is related to T. butchisonii Dodson \& D.E. Benn. from northern Peru and Ecuador, but according to Dodson \& Bennett (1989), in T. butchisonii, the lip is 13 to 15 -nerved, the callus is cordiform and unlobed, and the column is covered with bristles forming a hood. Other similar species are T. thomasii Dodson \& R. Escobar, and T. octavioi Dodson \& R. Escobar. The Ecuadorian T. thomasii has the petals and the lip with double marked longitudinal veins, the callus cordiform sligthtly convex, and the column crowned by bristles without differentiated tufts.
On the other hand, T. octavioi has smaller flowers, and the callus tongue-like, and unlobed.

Telipogon mesotropicalis Nauray \& A. Galán, sp. nov.

Type: PERU. Cusco: Paucartamabo, Kosñipata, Wayqecha, The Manu Biosphere Reserve, 13 10' 33" S, 71'35' 37" W, 2908 m, 27 Apr. 2007, W. Nauray \& M. Mamani 3770 (holotype, CUZ; isotypes, HGI, MA, MOL).

Illustrations: Fig. 11 and 10b.

Speciei Telipogon boissierianus Rchb. fil. similis, ab ea vero praesertim differens foliis floribusque maioribus et callo cordiforme.

Plant caulescent, terrestrial or epiphytic, about 20 $\mathrm{cm}$ tall. Stem $18 \mathrm{~cm}$, erect, leafy throughout. Leaves 4 


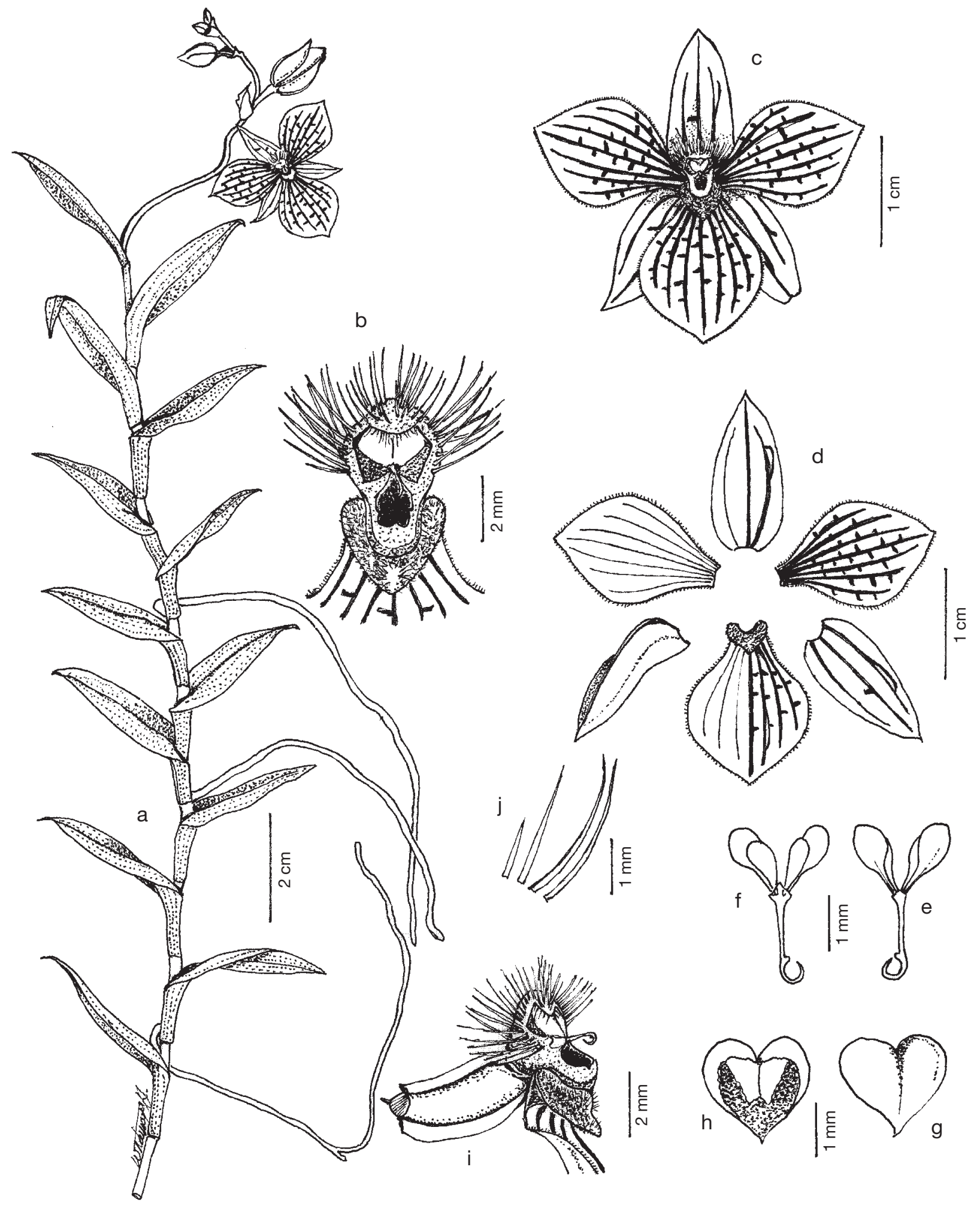

Fig. 11. Telipogon mesotropicalis: a, habit; b, column and callus in front view; c, flower in front view; d, dissected perianth; e, pollinarium in front view; $\mathbf{f}$, pollinarium in ventral view; $\mathbf{g}$, anther in front view; $\mathbf{h}$, anther in ventral view; $\mathbf{i}$, column, callus and ovary in lateral view; j, column bristles. All drawn from Nauray \& Mamani 3770 (HGI). 
$\times 1 \mathrm{~cm}$, ovate-lanceolate to oblanceolate, acuminate, sheath not articulated with the blade. Inflorescence and peduncle $5 \mathrm{~cm}$ long; peduncle cylindric, flexuous; raceme with 2-5 flowers, usually one open at a time; floral bract $1 \times 0.7 \mathrm{~cm}$, ovate-triangular, acuminate. Flowers $2.5-3 \mathrm{~cm}$ in diameter, normally not resupinate; pedicellate ovary $20 \mathrm{~mm}$ long, tricarinate; sepals 14-15 × 6-7 mm, lime green with purple veins, ovate, acute, concave, dorsally carinate, 3 -nerved; petals $15 \times 10 \mathrm{~mm}$, lemon yellow with purple longitudinal veins and short transverse lines, rhombic-elliptic, obtuse, margin completely ciliolate, 7 -nerved; lip $15 \times 12 \mathrm{~mm}$, similar in colour to the petals, rhombicelliptic, obtuse, margin completely ciliolate, 7 -nerved; callus $3 \times 3 \mathrm{~mm}$, purple, cordiform, hirsute in the front, velutinous in the rest of surface, the apical half free from the lip. Column $4 \times 3 \mathrm{~mm}$, pale purple, with three tufts of bristles around the anther; bristles to 3 $\mathrm{mm}$ long, longer in the two lateral tufts, pale purple, recurved to flexuous, acuminate or caudate apically; stigma quadrangular; anther $2 \times 2 \mathrm{~mm}$, hyaline purple, cordiform; stipe $1 \mathrm{~mm}$ long, hyaline purple; viscidium $0.7 \mathrm{~mm}$ long, hyaline orange, uncinate; pollinia 4 , bright yellow, in two dissimilar pairs, ovoid, larger pair $1.5 \times 0.7 \mathrm{~mm}$.

Etymology: The name refers to the Mesotropical Bioclimatic Belt of the Eastern Andes, the biogeographic unit where this species grows.

Distribution and ecology: Telipogon mesotropicalis grows in the cloud forest (2700-2900 m) with Chusquea sp. (Poaceae), Clusia sp. (Clusiaceae), Cavendisbia bracteata (Ruiz \& Pav. ex J. St.-Hil.) Hoerold (Ericaceae), Hesperomeles sp. (Rosaceae), Myrsine sp. (Myrsinaceae), and Weinmannia crassifolia Ruiz \& Pav. (Cunoniaceae); it flowers between April and November.

Additional specimen examined: PERU. Cusco: Paucartambo, Esperanza, 2700 m, Nov. 2006, M. Mamani s.n. (photograph USP).

Observations: Telipogon mesotropicalis differs to T. boissierianus Rchb.f. (holotype G!) in its larger leaves and flowers, ciliolate petal and lip margins, cordiform callus, and longer column bristles. Other related caulescent species are T. inmaculatus Christenson (Ecuador) and T. valenciae Dodson \& R. Escobar (Colombia). The petals and lip in T. inmaculatus are unmarked with coloured veins or transverse lines, and their basal margins are overlapping. In contrast to Telipogon mesotropicalis, $T$. valenciae has shorter petals and lip with brown longitudinal veins and transverse lines, and both are glabrous; furthermore, its callus is trilobed and not cordiform.
Telipogon santiagocastroviejoi Nauray, A. Galán \& R. Farfán, sp. nov.

Type: PERU. Cusco: Quispicanchis, Marcapata, Marcapata, 13 35' 06” S, 70 58' 12" W, 2864 m, 20 Apr. 2007, W. Nauray E R. Farfán 3764 (holotype, CUZ; isotypes, HGI, MOL).

Illustrations: Fig. 12 and 10c.

Speciei Telipogon tessellatus Lindl. similis, ab ea vero praesertim differens lateralibus petalis transverse rhomboideis et callo sagittato.

Plant caespitose, epiphytic, about $10 \mathrm{~cm}$ tall. Stem to $3 \mathrm{~cm}$, with few basal leaves. Leaves $5.5 \times 1.3 \mathrm{~cm}$, oblanceolate, acuminate, sheath articulated with the blade. Inflorescence and peduncle $5.5 \mathrm{~cm}$ long; peduncle compressed, alate, recurved; raceme with 2-5 flowers, usually one open at a time; floral bract $1.3 \times 1$ $\mathrm{cm}$, ovate-triangular, acuminate, dorsally carinate. Flowers $3-3.5 \mathrm{~cm}$ in diameter, normally resupinate; pedicellate ovary $30 \mathrm{~mm}$ long, trialate; sepals $16 \times 8$ $\mathrm{mm}$, translucent greenish, ovate, acuminate, dorsally alate, 3-nerved; petals $20 \times 24 \mathrm{~mm}$, pale yellow, with purple reticulated veins wider toward the margin, tranversely rhombic, obtuse, 9 to 11 -nerved with cross veins; lip $18 \times 24 \mathrm{~mm}$, similar in colour to the petals, transversely elliptic, acuminate, 17 -nerved with cross veins; callus $5 \times 4 \mathrm{~mm}$, purple, sagittatecordiform, convex, hirsute, the apical half free from of the lip. Column $2.5 \times 3 \mathrm{~mm}$, purple, cylindrical, crowned on top by bristles, rest of surface pubescent; bristles to $2.5 \mathrm{~mm}$ long, purple, rigid, acuminate or caudate apically; stigma circular; anther $3 \times 2 \mathrm{~mm}$, cordiform; stipe to $3 \mathrm{~mm}$ long, hyaline; viscidium 0.8 $\mathrm{mm}$ long, hyaline orange, uncinate; pollinia 4 , bright yellow, in two dissimilar pairs, ovoid, larger pair 1.5 $\times 0.7 \mathrm{~mm}$.

Etymology: Named in honor of Dr. Santiago Castroviejo Bolibar, botanist and researcher of the Neotropical Flora at the Real Jardín Botánico, Madrid.

Distribution and ecology: Telipogon santiagocastroviejoi is found in the cloud forest $(2800 \mathrm{~m})$ on Aegiphila mortoni Moldenke (Verbenaceae), Barnadesia borrida Muschl. (Asteraceae) and Myrsine sp. (Myrsinaceae). It flowers in April.

Observations: Telipogon santiagocastroviejoi is distinguished by the petals and lip coloured with veins reticulated, thicker towards the margin, the transverse petals, and the callus sagittate-cordiform, convex, and narrow toward the apex. It is similar to the other sympatric species T. tessellatus Lindl. (holotype K!), T. jimburensis Dodson \& R. Escobar, and T. thomasii Dodson \& R. Escobar, but differs in the different characters of the petals, lip, callus, and column. In $T$. 

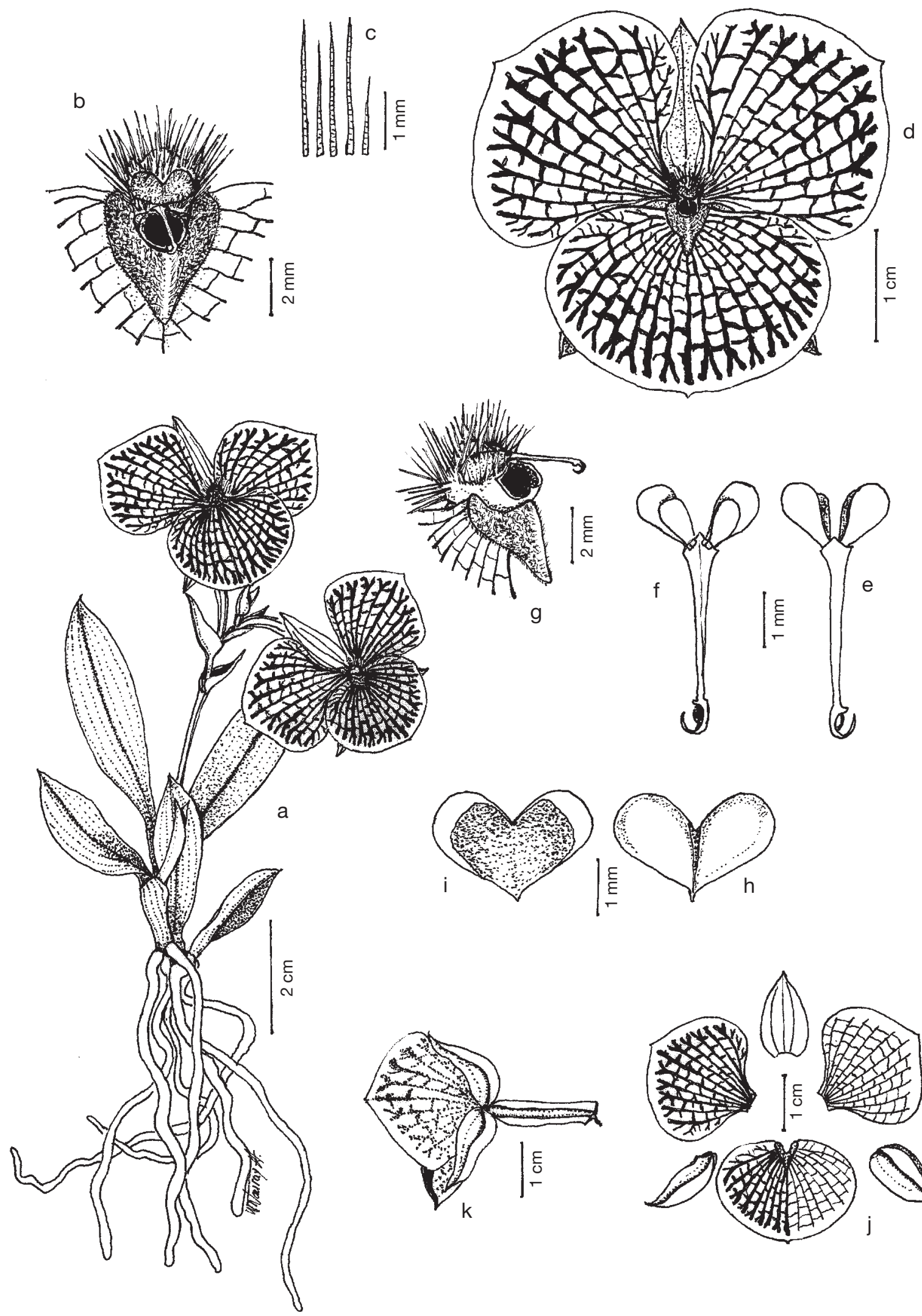

Fig. 12. Telipogon santiagocastroviejoi: a, habit; b, column and callus in front view; c, column bristles; d, flower in front view; e, pollinarium in front view; $\mathbf{f}$, pollinarium in ventral view; $\mathbf{g}$, column and callus in lateral view; $\mathbf{h}$, anther in front view; $\mathbf{i}$, anther in ventral view; j, dissected perianth; k, flower and ovary in lateral view. All drawn from Nauray 3764 \& Farfán (HGI). 


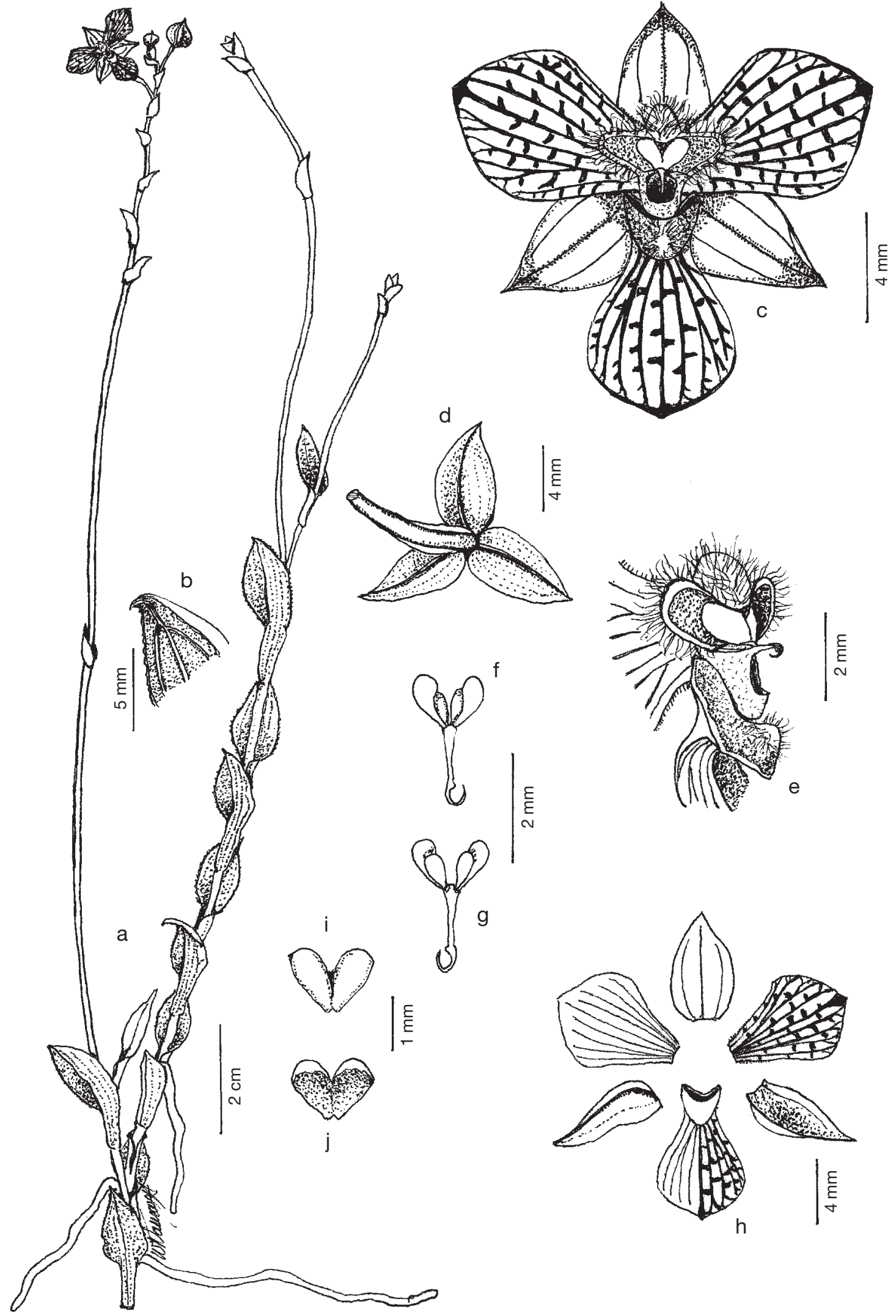

Fig. 13. Telipogon tupayachii: a, habit; b, leaf apex; $\mathbf{c}$, flower in front view; d, ovary and sepals in dorsal view; e, column and callus in lateral view; $\mathbf{f}$, pollinarium in front view; $\mathbf{g}$, pollinarium in ventral view; $\mathbf{h}$, dissected perianth; $\mathbf{i}$, anther in front view; $\mathbf{j}$, anther in ventral view. All drawn from Nauray \& Mamani 3768 (HGI). 
tessellatus, the petals are elliptic not transverse, and the callus is pad shaped. According to Dodson \& Dodson (1989), T. jimburensis has the petals broadly elliptic, 13-nerved, the callus trilobed, and the column with an apicule extended below the stigma. Telipogon thomasii has the petals and the lip with double marked longitudinal veins, the callus broadly cordiform, and the column larger than T. santiagocastroviejoi. Furthermore, in T. santiagocastroviejoi, the bristles (related to the column) are longer than in T. jimburensis and T. thomasii.

Telipogon tupayachii Nauray \& A. Galán, sp. nov.

Type: PERU. Cusco: Paucartamabo, Kosñipata, Tres Cruces-Acjanaco, National Park of Manu, $13^{\circ} 9^{\prime}$ 49" S, 71³7' 57" W, 3471 m, 25 Apr. 2007, W. Nauray \& M. Mamani 3768 (holotype, CUZ; isotypes, HGI, MA, MOL).

Illustrations: Fig. 13 and 10d.

Speciei Telipogon phutupatamarcensis W. Galiano, P. Núñez \& A. Tupayachi similis, ab ea vero praesertim differens lateralibus petalis atque labello venis purpurascentibus, marginem versus ramificatis, transversisque lineolis item purpurascentibus ornatis et columna longis pilis cooperta.

Plant caulescent, terrestrial, about $40 \mathrm{~cm}$ tall. Stem $30 \mathrm{~cm}$ long, erect, leafy throughout. Leaves $3 \times 1 \mathrm{~cm}$, ovate-lanceolate, acuminate, margin erose, sheath not articulated with the blade. Inflorescence and peduncle $12 \mathrm{~cm}$ long; peduncle cylindric, flexuous; raceme with 5-12 flowers, usually one open at a time; floral bract $0.7 \times 0.5 \mathrm{~cm}$, ovate-triangular, conduplicate, acute. Flowers $1.5 \mathrm{~cm}$ in diameter, normally resupinate; pedicellate ovary $10-15 \mathrm{~mm}$ long, tricarinate; sepals $7 \times 4 \mathrm{~mm}$, pale lemon green with veins and apical spots purplish, ovate, acuminate, concave, 3 -nerved; petals $8 \times 6 \mathrm{~mm}$, pale lemon yellow with veins ramified toward the margin and transverse lines purplish, obovate-rhombic, obtuse, basal margin ciliolate, 9-nerved; lip $8.5 \times 5.5 \mathrm{~mm}$, similar in colour to the petals, obovate, obtuse, basal margin ciliolate, 7 to 9-nerved; callus $3 \times 3 \mathrm{~mm}$, purplish, conical-sagittate, obtuse, with a hirsute knob in the front, the apical half free from the lip. Column 2.5-3 $\times$ 4-4.5 mm, purplish, trilobulate in the part that surrounds the anther, covered with long recurved or flexuous long pale purple hairs; stigma quadrangular; anther $1.25 \times 1.5 \mathrm{~mm}$, hyaline purple, cordiform; stipe $1 \mathrm{~mm}$ long, hyaline purple; viscidium $0.5 \mathrm{~mm}$ long, hyaline orange, uncinate; pollinia 4 , bright yellow, in two dissimilar pairs, ovoid, larger pair $1 \times 0.5 \mathrm{~mm}$.

Etymology: Named in honor of M. Sc. Alfredo Tupayachi Herrera, professor and botanist at the Universidad Nacional de San Antonio Abad del Cusco.
Distribution and ecology: Telipogon tupayachii grows in the limit between the elfin forests and the humid Puna (3400 m), with Clethra sp. (Clethraceae), Diplostephium sp., Gynoxis sp. (Asteraceae), Myrsine sp. (Myrsinaceae), and Weinmannia micropbylla Kunth (Cunoniaceae); it flowers in April.

Observations: Telipogon tupayachii differs to $T$. phuyupatamarcensis W. Galiano, P. Núñez \& A. Tupayachi (holotype CUZ!) in the petals and lip with purplish veins branched towards the margin and transverse purplish lines, the sagittate-conical callus and the column with longer and denser hairs. Material of T. tupayachii was included in the holotype material of T. phuyupatamarcensis. The flowers of T. tupayachii are reminescent of the genus Trichoceros Kunth, but the plants are caulescent without pseudobulbs.

\section{Additional remarks and conclusions}

After the description of these new species, it seems that T. benedicti, T. boissierianus, T. papilio, T. tessellatus, and T. venustus are not present in southern Peru. Telipogon benedicti grows in Bolivia, and the Peruvian records are based on misidentifications and/or a broad concept of the species. The holotype of T. boissierianus has no specific locality in Peru, and is known only from this collection. The distribution of T. papilio includes Colombia, Ecuador and northern Peru; however, the records for these species in Cusco correspond to T. antisuyuensis and T. peruvianus T. Hashim. (holotype TNS!). At present, T. tessellatus is only registered for Ecuador; the description by Dodson \& Bennett, (1989) for Peru is very different from the holotype. An additional revision indicates that T. cuscoensis Nauray \& Christenson (holotype CUZ!) is synonymous of T. phalaenopis Braas, the flowers are very similar, even their columns have lateral bristles with capitate apex. As a result of these observations, the total number of Telipogon species (sensu stricto) recognized for the Peruvian flora is 46 (see Appendix).

\section{Acknowledgements}

This work was conducted within the framework of a $\mathrm{PhD}$ thesis supported by the Russell E. Train Program in Education for Nature-World Wildlife Fund, agreement No. RP53. The specimens were collected by authorizations of the Natural Resources National Institute of Peru 001C/C2007 and 043-2007, and CITES 09810.

We wish to express our gratitude to Dr. Ernst Vitek, Ing. David E. Bennett, Stig Dalström and the curators of the consulted herbaria. We thank Dr. José Alfredo Vicente Orellana, Dr. Joan Font, and the reviewers for their careful comments on early versions of the manuscript. We thank Marlene Mamani, William Farfán, René Farfán, Norma Salinas, Karina Garcia, Tatiana Espinoza, Salvador Salvador, Martin Kekenhoff, Richard Titto, Ángela Rozas, 
Miquel Jover and Marta Doncel for their assistance in this study. Andrea Galán and Josh Rapp helped with linguistic assistance, and M. Laínz corrected Latin diagnoses. Finally, we thank the park rangers of Machu Picchu and Manu protected areas.

\section{References}

Bennett, D.E. \& Christenson, E.A. 1998. Icones Orchidacearum Peruvianum III. A. Pastorelli. Lima-Sarasota.

Bennett, D.E. \& Christenson, E.A. 2001. Icones Orchidacearum Peruvianum IV. A. Pastorelli. Lima-Sarasota.

Braas, L.A. 1981. Ergänzungen zur Gattung Telipogon HBK (Orchidaceae)-I. Die Orchidee (Hamburg) 32: 238-248.

Braas, L.A. 1982. Ergänzungen zur Gattung Telipogon HBK (Orchidaceae)-II. Die Orchidee (Hamburg) 33: 91-100.

Braas, L.A. 1985. Ergänzungen zur Gattung Telipogon HBK (Orchidaceae)-III. Die Orchidee (Hamburg) 36: 73-79.

Brako, L. \& Zarucchi, J. 1993. Catálogo de las Angiospermas y Gimnospermas del Perú. Monogr. Syst. Bot. Missouri Bot. Gard. 45. St. Louis.

Dodson, C.H. 2004. Native Ecuadorian Orchids, Vol. 5: Rodriguezia to Zygosepalum. Dodson Trust. Quito.

Dodson, C.H. \& Bennett, D.E. 1989. Icones Plantarum Tropicarum, series II, Fascicle 2, Orchids of Peru. Missouri Botanical Garden. St. Louis.

Dodson, C.H. \& Dodson, P.M. 1989. Icones Plantarum Tropicarum, series II, Fascicle 1, Orchids of Ecuador. Missouri Botanical Garden. St. Louis.

Dodson, C.H. \& Escobar, R. 1987. The Telipogons of Costa Rica (I). Orquideología 17: 1-69.

Dodson, C.H. \& Escobar, R. 1993a. Ocho especies nuevas del género Telipogon en Colombia. Orquideología 18: 237-260.

Dodson, C.H. \& Escobar, R. 1993b. El género Telipogon en Panamá. Orquideología 18: 273-290.

Foldats, E. 1970. Orchidaceae. In: Lasser T. (ed.), Flora de Venezuela, Vol. 15(5). Instituto Botánico, Dirección de Recursos Naturales Renovables, Ministerio de Agricultura y Cría. Caracas.

Galiano, W., Núñez, M.P., Tupayachi, A. \& Calatayud, G. 2003. Una nueva especie de Telipogon (Orchidaceae) del sureste peruano. Cantua 11: 11-14.

Govaerts, R. 2008. World Checklist of Monocotyledons. The Royal Botanic Gardens. Kew. [http://apps.kew.org/wcsp/prepare Checklist.do? checklist $=$ monocots $\% 40 \% 4002424012008185$ 9546].

Hashimoto, T. 1990. New and Noteworthy Orchids from Peru. Bulletin of the National Science Museum of Tokyo, Ser. B 16: 21-27.

Kränzlin, F.W.L. 1919. Beiträge zur Kenntnis der Gattung Telipogon H.B.K. Annalen des Naturbistorischen Museums in Wien 33: 9-38.

Lindley, J. 1847. New garden plant: Telipogon obovatus. Edwards's Botanical Register 33: plate 27.

Moretz, C.C. \& Farfán, W. 2003. A New Telipogon from Southern Peru. Orchid Review 111: 239-241.

Nauray, W. \& Christenson, E.A. 2003. Telipogons from Peru. Two new species from Machu Picchu and environs. Orchids 72: 696-698.

Reichenbach, H.G. 1854. Orchideae Warscewiczianae recentiores. Bonplandia 2: 96-102.

Reichenbach, H.G. 1856. Orchideae Ruizianae et Pavonianae Musaei Boissieriani. Bonplandia 4: 210-217.

Reichenbach, H.G. 1858. Xenia Orchidacea: Beiträge zur Kenntniss der Orchideen. Vol. 1. F.A. Brockhaus. Leipzig.
Reichenbach, H.G. 1877a. Orchideae Roezlianae novae seu criticae. Linnaea 41: 1-16.

Reichenbach, H.G. 1877b. Orchidiographische Beiträge. Linnaea 41: 17-98.

Schlechter, R. 1920. Die Orchideenfloren der südamerikanischen Kordillerenstaaten, II. Colombia. Repertorium Specierum Novarum Regni Vegetabilis 7: 1-301.

Schlechter, R. 1921. Die Orchideenfloren der südamerikanischen Kordillerenstaaten, IV. Peru. Repertorium Specierum Novarum Regni Vegetabilis 8: 1-182.

Schweinfurth, C. 1960. Orchids of Peru. Fieldiana Botany 30: 787 1026.

Williams, N.H., Whitten, W.M. \& Dressler, R.L. 2005. Molecular systematics of Telipogon (Orchidaceae: Oncidiinae) and its allies: nuclear and plastic DNA sequence data. Lankesteriana 5: 163-184.

\section{APPENDIX}

CHECKLIST OF THE SPECIES OF TELIPOGON RECOGNIZED FROM PERU WITH THEIR AUTHORS, CITATION OF PROTOLOGUE, AND DEPARTMENTAL DISTRIBUTION WITHIN PERU (IN BRACKETS)

T. alegriae D.E. Benn. \& Christenson, Ic. Orchidac. Peruv., tab. 779 (2001) [Huancavelica].

T. antisuyuensis Nauray \& A. Galán, sp. nov. [Cusco].

T. antonietae D.E. Benn. \& R. Fernández G., Publ. Mus. Hist. Nat. Univ. Nacion. Mayor San Marcos, Bot. 36: 2 (1992) [Junín].

T. ariasii Dodson \& D.E. Benn., Ic. Pl. Trop. 2, tab. 184 (1989) [Junín].

T. atropurpurea D.E. Benn. \& R. Fernández G., Publ. Mus. Hist. Nat. Univ. Nacion. Mayor San Marcos, Bot. 36: 9 (1997) [Piura].

T. auriculata D.E. Benn. \& Christenson, Ic. Orchidac. Peruv., tab. 780 (2001) [Junín].

T. austroperuvianus Nauray \& A. Galán, sp. nov. [Cusco].

T. boissierianus Rchb. f., Bonplandia 4: 213 (1856) [?].

T. campoverdei D.E. Benn. \& R. Fernández G., Publ. Mus. Hist. Nat. Univ. Nacion. Mayor San Marcos, Bot. $36: 6$ (1992) [Piura].

T. casadevalliae Nauray, A. Galán \& M. Mamani, sp. nov. [Cusco].

T. collantesii D.E. Benn. \& Christenson, Ic. Orchidac. Peruv., tab. 782 (2001) [Huancavelica].

T. dalstromii Dodson, Ic. Pl. Trop., 10, tab. 990 (1984) [Piura].

T. davidsonii D.E. Benn. \& Christenson, Ic. Orchidac. Peruv., tab. 783 (2001) [Piura].

T. farfanii Nauray \& A. Galán, sp. nov. [Cusco].

T. fritillum Rchb. f. \& Warsz., Bonplandia 2: 101 (1854) [Peru, department unknown].

T. genegeorgei D.E. Benn. \& R. Fernández G., Publ. Mus. Hist. Nat. Univ. Nacion. Mayor San Marcos, Bot. 36: 4 (1992) [Junín]. 
T. gnomus Schltr., Repert. Spec. Nov. Regni Veg. Beih. 9: 114 (1921) [Cajamarca].

T. gymnostele Rchb.f., Linnaea 41: 70 (1877) [Peru, department unknown].

T. hauschildianus Braas, Orchidee (Hamburg) 33(3): 92 (1982) [Junín].

T. hercules Rchb. f. ex Kraenzl., Ann. Nat. Mus. Wien 33: 27 (1920) [Peru, department unknown].

T. hutchinsonii Dodson \& D.E. Benn., Ic. Pl. Trop. 2, tab. 188 (1989) [Amazonas].

T. intis Braas, Orchidee (Hamburg). 32(6): 245 (1981) [Amazonas].

T. javiercastroviejoi Nauray \& A. Galán, sp. nov. [Cusco].

T. jucusbambae Dodson \& R. Escobar, Orquideologia 21(1): 65 (1998) [San Martín].

T. kosnipatensis Farfán, Nauray \& A. Galán, sp. nov. [Cusco].

T. luerii Dodson \& D.E. Benn., Ic. Pl. Trop. 2, tab. 190 (1989) [Amazonas, Cajamarca].

T. machupicchuensis Nauray \& Christenson, Orchids 72(9): 697 (2003) [Cusco].

T. marleneae Nauray \& A. Galán, sp. nov. [Cus$\mathrm{co}$.

T. mendiolae Dodson \& D.E. Benn., Ic. Pl. Trop. 2, tab. 191 (1989) [Piura].

T. mesotropicalis Nauray \& A. Galán, sp. nov. [Cusco].

T. obovatus Lindl., Bot. Reg. 1847, sub tab. 27 (1847) [Peru, department unknown].

T. papilio Reichb. f. \& Warsz., Bonplandia 2: 101 (1854) [Piura].
T. peruvianus T. Hashim., Bull. Nation. Sci. Mus., Tokio, B. 16(1): 21 (1990) [Cusco].

T. phalaenopsis Braas, Orchidee 32(6): 246 (1981) [Syn.: T. cuscoensis Nauray \& Christenson, Orchids 72(9): 696 (2003); Amazonas, Cusco].

T. phuyupatamarcensis W. Galiano, P. Núñez \& A. Tupayachi, Cantua 11: 11 (2003) [Cusco].

T. piyacnuensis D.E. Benn. \& Christenson, Ic. Orchidac. Peruv., tab. 785 (2001) [Pasco].

T. radiatus Rchb. f., Linnaea 41: 70 (1877) [Peru, department unknown].

T. rhombipetalus C. Schweinf., Amer. Orchid Soc. Bull. 15: 180 (1946) [Cajamarca].

T. salinasiae Farfán \& Moretz, Orchid Rev. 111(1252): 239 (2003) [Cusco].

T. santiagocastroviejoi Nauray, A. Galán \& R. Farfán, sp. nov. [Cusco].

T. sayakoae D.E. Benn. \& Christenson, Arnaldoa 6(1): 61 (1999) [Pasco].

T. suarezii D.E. Benn. \& Christenson, Ic. Orchidac. Peruv., tab. 787 (2001) [Huancavelica].

T. tayacajaensis D.E. Benn. \& Christenson, Ic. Orchidac. Peruv., tab. 788 (2001) [Huancavelica].

T. tupayachii Nauray \& A. Galán, sp. nov. [Cusco].

T. urceolatus C. Schweinf., Amer. Orch. Soc. Bull. 16: 292 (1947) [Huanuco].

T. vargasii C. Schweinf., Amer. Orch. Soc. Bull. 15: 290 (1946) [Cusco].

Associate Editor: C. Ulloa Received: 4-III-2008 Accepted: $12-\mathrm{V}-2008$ 


\section{Erratum}

Nauray Huari, W. \& Galán de Mera, A. 2008. Ten new species of Telipogon (Orchidaceae, Oncidiinae) from southern Peru. Anales del Jardín Botánico de Madrid 65(1): 73-95

Dr. Blanca León has brought to our attention that Telipogon kosnipatensis was described with the same type that the previous T. javiercastroviejoi. This was un unfortunate mistake produced when the paper was translated to the English. In order to avoid any nomenclatural disturbance we have decided to change the name of this species with a new type:
Telipogon paucartambensis Farfán, Nauray \& A. Galán, nom. nov.

T. kosnipatensis Farfán, Nauray \& A. Galán, Anales Jard. Bot. Madrid 65(1): 85 (2008), nom. illeg.

Type: PERU. Cusco: Paucartambo, Kosñipata, Trocha Unión, Manu National Park, Nov. 2006, W. Farfán TU-09 (holotype, CUZ; isotype, HGI).

William Nauray Huari \& Antonio Galán de Mera 